Article

\title{
Synthetic Approaches to a Challenging and Unusual Structure-An Amino-Pyrrolidine Guanine Core
}

\author{
Rafael Rippel ${ }^{\mathbb{D}}$, Luís Pinheiro, Mónica Lopes, Ana Lourenço, Luísa M. Ferreira *DiD and \\ Paula S. Branco *(D)
}

LAQV-REQUIMTE, NOVA School of Science and Technology, 2829-516 Caparica, Portugal;

r.rippel@campus.fct.unl.pt (R.R.); 1.pinheiro@campus.fct.unl.pt (L.P.); mam.lopes@campus.fct.unl.pt (M.L.); ana.lourenco@fct.unl.pt (A.L.)

* Correspondence: lpf@fct.unl.pt (L.M.F.); paula.branco@fct.unl.pt (P.S.B.)

Academic Editors: David Díez and María Ángeles Castro

Received: 10 January 2020; Accepted: 10 February 2020; Published: 12 February 2020

check for updates

\begin{abstract}
The synthesis of an unreported 2-aminopyrrolidine-1-carboxamidine unit is here described for the first time. This unusual and promising structure was attained through the oxidative decarboxylation of amino acids using the pair of reagents, silver(I)/peroxydisulfate $\left(\mathrm{Ag}(\mathrm{I}) / \mathrm{S}_{2} \mathrm{O}_{8}{ }^{2-}\right)$ followed by intermolecular (in the case of L-proline derivative) and intramolecular trapping (in the case of acyl L-arginine) by $N$-nucleophiles. The L-proline approach has a broader scope for the synthesis of 2-aminopyrrolidine-1-carboxamidine derivatives, whereas the intramolecular cyclization afforded by the L-acylarginines, when applied, results in higher yields. The former allowed the first synthesis of cernumidine, a natural alkaloid isolated in 2011 from Solanum cernuum Vell, as its racemic form.
\end{abstract}

Keywords: amino acid decarboxylation; cyclic-guanidine; Cernumidine; radical decarboxylation

\section{Introduction}

Small molecules are desirable for the pharmaceutical industry and medicinal chemistry where the search for "hits" with specific effects on cells are essential. The drug discovery community surely knows the classes of molecules associated with increased clinical success [1,2], and a large portion of the approved drugs are small molecules containing nitrogen-based aromatic heterocycles such as pyrazoles, imidazoles, benzoimidazoles, triazoles, and 2-amine-pyrimidine moieties [3]. Being aware of the dimension of the drug-like chemical space able to accommodate an enormous diversity of small molecules [4], chemical biology researchers started to look at fragment-based drug discovery as a different approach [5]. Without detracting from chemical synthesis, nature is still the best source of diversity, but problems arise when more material is needed to pursue applicability studies. Chemical modifications to improve therapeutic action, complete synthesis, and semisynthesis contribute significantly to this purpose [6,7]. In their 2016 review paper, Newman and Cragg make a detailed analysis of the relevance of natural products in the origin of new drugs from 1984 to 2014 [8]. About one-third of all approved drugs classified as "small molecules" in this period are natural products, derived from natural or synthetic products but with a natural pharmacophore. Guanidine derivatives can be found in several natural products from diverse origin $[9,10]$ and this structural unit is present as a building block in various pharmaceuticals such as rosuvastatin a cholesterol biosynthesis inhibitor, [11] guanabenz used clinically as an antihypertensive agent, [12] imatinib a tyrosine kinase inhibitor [13] used as an anticancer drug and the blockbuster drug used to treat peptic ulcers and cimetidine a histamine $\mathrm{H} 2$ receptor antagonist that inhibits stomach acid production [14]. Considered to be one of the strongest organic bases $\left(\mathrm{pK}_{\mathrm{HA}}=13.6\right)$ guanidine has the capacity to bind to carboxylates, phosphates and metals with the guanidinium cation engaging 
special interactions between ligand/receptor or enzyme/substrate [15]. Because guanidines are super bases and oxoanion hosts, they are good supporting ligands in organometallic and coordination chemistry, and can also be used as catalysts [16]. Cernumidine (1) (Figure 1) is an alkaloid isolated in 2011 [17] presenting an unusual cyclic-guanidine core and displaying inhibition of interleukine-8 production by HT-29 colon carcinoma cells [18-21]. Cernumidine and other isomeric compounds isolated from the Brazilian native tree used in folk medicine, Solanum cernuum Vell., present a never reported 2-aminopyrrolidine-1-carboxamidine unit with five consecutive $\mathrm{C}-\mathrm{N}$ bonds that, although structurally very simple and with only a labile stereogenic center, presents a major synthetic challenge to a synthetic chemist [22,23].

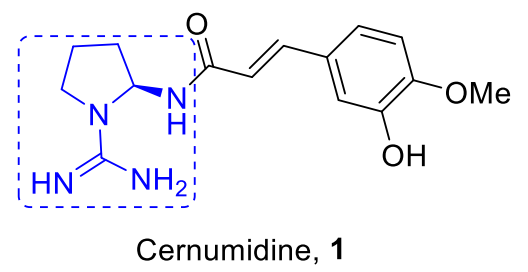

Figure 1. Structure of cernumidine (1); in marked blue is the 2-aminopyrrolidine-1-carboxamidine unit presenting the cyclic-guanidine core.

Previous efforts on the synthesis of a cyclic-guanidine core were reported in the work of Ascenzi et al. who described the biological synthesis of the hemiaminal, 2-hydroxopyrrolidin-1-yl carboxamidine from agmatine ((4-aminobutyl)guanidine) using copper aminoxidase from Pisum sativum L. in an oxidative deamination process. The formation of the cyclic product $N$-amidino-2-hydroxypyrrolidine should occur within the enzyme's catalytic center since the presence of free 4-guanidobutyraldehyde (shown within square brackets in Figure 2a) was never detected [24]. Although not precisely to attain a cyclic-guanidine core, Boto et al. developed a process aimed at the oxidative decarboxylation of a L-ornithine methyl carbamate derivative using the system (diacetoxyiodo)benzene or iodosylbenzene at room temperature followed by intramolecular cyclization to a 2-aminopyrrolidine nucleus [25]. In this, and other reported works, they showed that the carboxyl radical evolves by loss of carbon dioxide to produce a carbon radical which, in turn, undergoes oxidation to an $N$-acyliminium ion intermediary demonstrated through inter- and intramolecular trapping with oxygen, nitrogen and carbon nucleophiles [26-28]. They also showed that the reaction with proline is limited to $N$-protected carbamates (Figure 2b) [27]. In a very recent work, Silva et al. [29] on trying to elucidate the metabolic pathway of crambescins, suggested arginine and fatty acids as precursors for the broad chemical diversity of this family. Their hypothesis was corroborated with a bio-inspired synthesis of crambescin A2-448. Starting from arginine, they postulate that the oxidative decarboxylation generates in situ a highly reactive pyrrolinium salt, and through a Biginelli-like reaction between C-2/C-3 activated fatty acids and a central guanidinylated pyrrolinium on a cascade sequence the bicyclic system of crambescins was obtained in a single operation (Figure 2c). There are several procedures available to effect oxidative decarboxylation of amino acids. Previously we have already mentioned the methodology of Boto et al. involving the use of the pair of oxidizing reagents diacetoxiiodobenzene/ $\mathrm{I}_{2}\left(\mathrm{DIB} / \mathrm{I}_{2}\right)[25-28]$. Others, combined this process with a Friedel-Crafts reaction in which they used aromatic rings (benzene, furan, thiophene, among others) as nucleophiles to react with the acyliminium ion formed after the oxidative decarboxylation [30,31]. Also using a hypervalent iodine reagent, the $o$-iodoxybenzoic acid, Akamanchi et al. [32] pursued the decarboxylation of amino acids to nitriles in aqueous ammonia. Other methods for amino acid decarboxylation include the use of hypohalides such as hypochlorite and hypobromite [33], N-bromosuccinimide [34], or the pair of reagents, silver(I)/peroxydisulfate $\left(\mathrm{Ag}(\mathrm{I}) / \mathrm{S}_{2} \mathrm{O}_{8}{ }^{2-}\right)$ applied for the first time by Stewart et al. [35] for the preparation of aldehydes. 


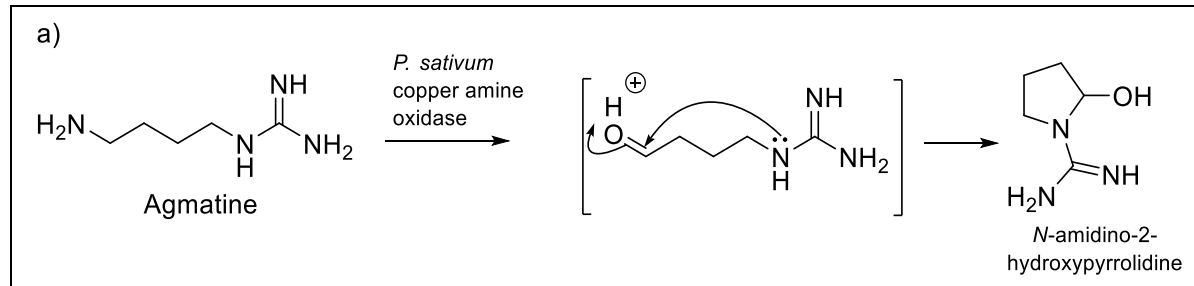

b)

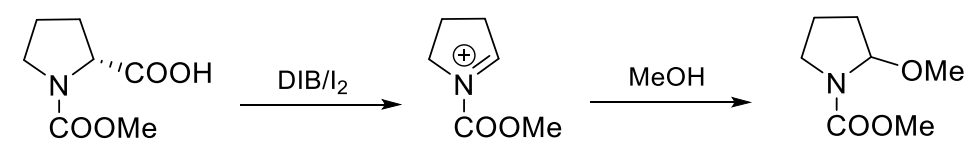

c)

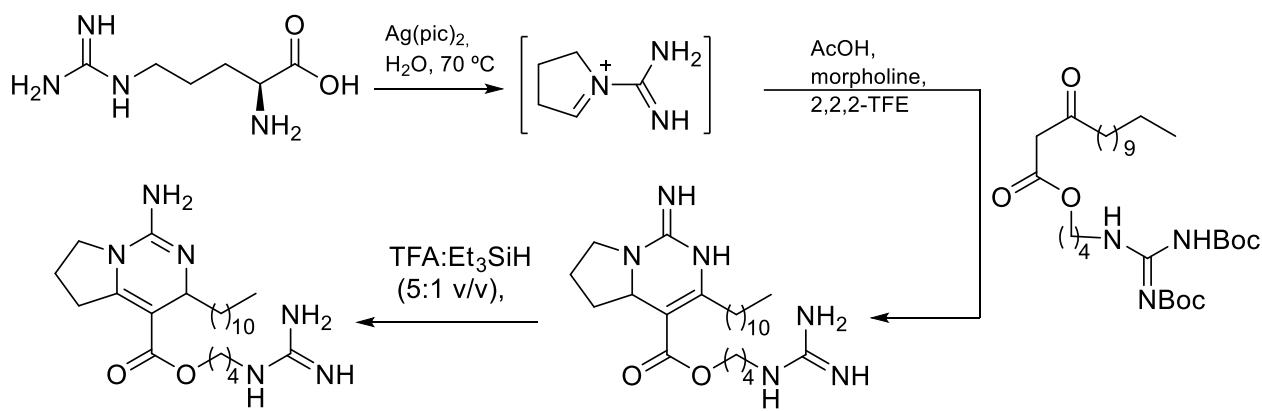

$( \pm)$-crambescin A2-448

(+)-didehydrocrambescin A2-448

Figure 2. Reported efforts on the synthesis of a cyclic-guanidine core. Works from: (a) Ascenzi, P., et al. [24], (b) Boto, A., et al. [25,27], and (c) Silva et al [29].

The formation of the metastable ion Ag(II) generated in situ, can be isolated by chelation with nitrogen aromatic ligands such as picolinic acid to form the silver picolinate salt (II), $\mathrm{Ag}(\mathrm{pic})_{2}$. The work of Clarke et al. [36] and Silverman and Zelechonok [37] helped to elucidate the mechanism of the oxidative decarboxylation reaction with amino acids. Moreover, the synergistic effect of $\mathrm{Cu}$ (II) on this system which can act as a co-catalyst that facilitates the oxidation of the alkyl radical to an alkene, alcohol, aldehydes, ketones or even imides has been addressed [38-40]. In addition to silver, the metal catalysed approaches for the decarboxylative coupling of amino acids can also be performed with $\mathrm{Fe}(\mathrm{I})$ [41], $\mathrm{Co}(\mathrm{II})$ [42], $\mathrm{Cu}(\mathrm{I})$ [43,44] Ce(IV) [45]. Although several methodologies have been developed in the last ten years, to the best of our knowledge, the decarboxylation of amino acids with basic residues in the side chain remains elusive. Moreover, the use of nitrogen nucleophiles in metal catalysed decarboxylative coupling was never reported for intermolecular reactions [46].

Here, we report for the first time the synthesis of the cyclic-guanidine core, the 2-aminopyrrolidine-1-carboxamidine unit (Figure 1) that ultimately allows us to synthesize the natural product cernumidine (1) and analogues in its racemic form.

\section{Results and Discussion}

Two complementary strategies were applied for the synthesis of 2-aminopyrrolidine1-carboxamidine derivatives (Scheme 1) starting from L-proline and L-arginine through their guanidine (2) and acyl derivatives (3), respectively. The delineated synthetic method involves two approaches: (i) oxidative decarboxylation of carbamimidoyl-t-proline (2) followed by the intermolecular trapping 
of the iminium intermediate by nucleophiles and, (ii) oxidative decarboxylation of (3) followed by intramolecular trapping of the acyliminium intermediate.

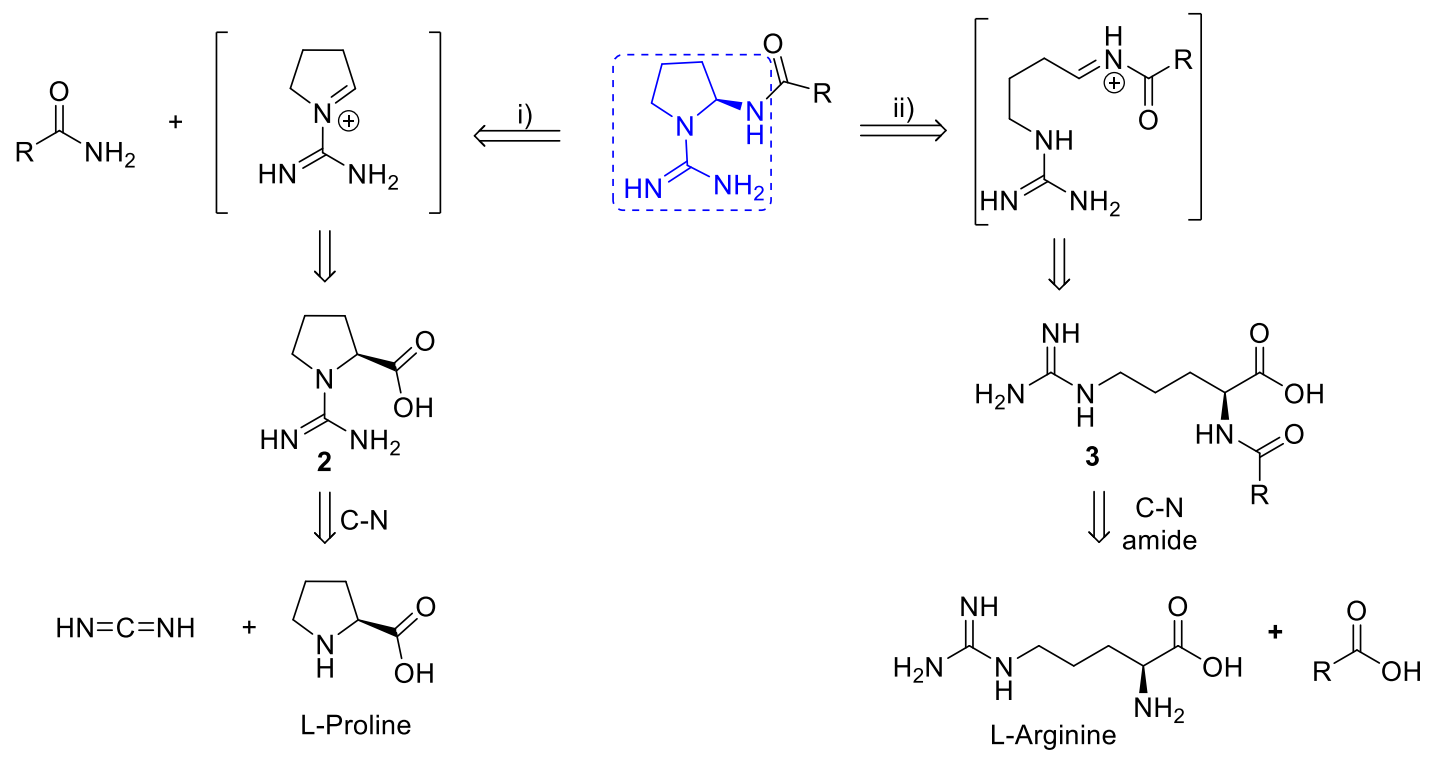

Scheme 1. Retrosynthetic approach to the synthesis of 2-aminopyrrolidine-1-carboxamidine derivatives.

\subsection{Studies on the Oxidative Decarboxylation of L-arginine Derivatives (3)}

Several L-arginine derivatives were synthesized as described in Table 1. Following the literature procedure [47] N-benzoylarginine (3a) was obtained in $47 \%$ yield by reaction with benzoyl chloride.

Table 1. Procedures used via acyl chloride (Method A) or coupling reagent (Method B) for the preparation of $N^{\alpha}$-L-arginine acyl derivatives (3).

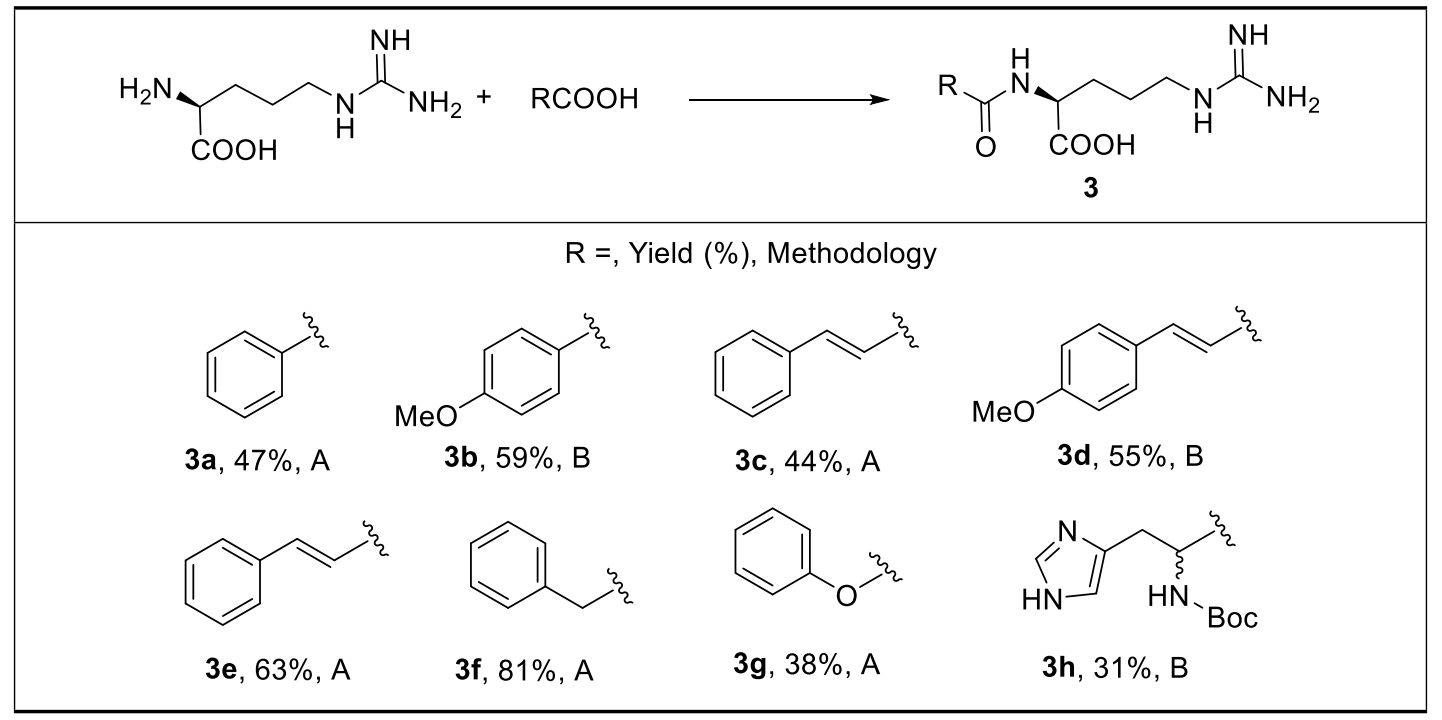

Method A: Acyl chloride (1.1 equiv.), L-arginine (1 equiv.) in water $(1.15 \mathrm{M}), \mathrm{Na}_{2} \mathrm{CO}_{3} 2$ equiv. $(\mathrm{pH} \approx 10)$ at $0{ }^{\circ} \mathrm{C}$ then $24 \mathrm{~h}$ r.t.; Method B: Carboxylic acid (1,2 equiv.) in dry $\mathrm{CH}_{2} \mathrm{Cl}_{2}(0.5 \mathrm{M})$, $\mathrm{CDI}$ (1.5 equiv.) then L-arginine (1 equiv.) $0.5 \mathrm{M}$ in DMF and DMAP (0.1 equiv.). For each compound the synthetic method used is assigned bellow it.

Other acyl chlorides were used when commercially available (as in the case of the synthesis of compound $3 \mathrm{~g}$ ) or in situ prepared by reaction of the corresponding carboxylic acid with $\mathrm{SOCl}_{2}$ (Method A-compounds $\mathbf{3} \mathbf{c}, \mathbf{3 e}$, and $\mathbf{3} \mathbf{f}$ were thus prepared). Alternatively, compounds $\mathbf{3 b}, \mathbf{3 d}$, and $\mathbf{3 h}$ were prepared using carbonyldiimidazole (CDI) as coupling reagent (Method B) [48]. Next, we turned our 
attention to the oxidative decarboxylation of $N^{\alpha}$-acyl-L-arginine derivatives (3) (Scheme 2). Based on the literature [29], we propose that the oxidative decarboxylation of 3 will generate an iminium intermediate (5), which goes through an intramolecular cyclization to 4 . Depending on the reaction conditions, 5 can be trapped by water to the hemiaminal that is further oxidized to the imide (6) or cleavage to the aldehyde (7) and the corresponding amide.<smiles>[R]C(=O)N[C@@H](CCCNC(=N)N)C(=O)O</smiles>

oxidative decarboxylation<smiles>[R]C(=O)N[C@@H]1CCCN1C(=N)N</smiles><smiles>[Y]CCCNC(=N)N</smiles>

4<smiles>[R]C(=O)NC(=O)CCCNC(=N)N</smiles>

6

Scheme 2. Proposed mechanism for the oxidative decarboxylation of $N^{\alpha}$-acyl-L-arginine derivatives (3) to 2-aminopyrrolidine-1-carboxamidine derivatives (4).

Screening of the reaction conditions and results are presented in Table 2. The first assays for the oxidative decarboxylation were performed on derivative 3a using the pair of oxidizing reagents diacetoxyiodobenzene/iodine (DIB/ $\left.\mathrm{I}_{2}\right)$ [25,49]. After several attempts, when a mixture of acetic acid and DCM was used as solvent (Table 2, entry 7) compound 4 a was obtained in 59\% yield, probably due to the higher solubility of $\mathbf{3 a}$ in this solvent mixture.

Next, we decided to turn our attention to the procedure described by Zelechonok [37] and use the pair of reagents $\mathrm{AgNO}_{3} /\left(\mathrm{NH}_{4}\right)_{2} \mathrm{~S}_{2} \mathrm{O}_{8}$. These conditions lead to much faster reactions and have the advantage that they can be performed in water, which is very suitable for these substrates. It is worth to mention that since the physical separation of $\mathbf{4 a}$ and $\mathbf{6 a}$ proved to be challenging, from there on whenever the formation of $\mathbf{6 a}$ was observed only relative amounts of each product will be described in Table 2. Using $\mathrm{AgNO}_{3} /\left(\mathrm{NH}_{4}\right)_{2} \mathrm{~S}_{2} \mathrm{O}_{8}$ (0.1:1.2) 39\% conversion to compound 4 a was observed together with compound $\mathbf{6 a}$ (Table 2 , entry 8 ). The formation of imides in these conditions were already reported by Huang [40] on the oxidative decarboxylation of $\mathrm{N}$-acyl amino acids induced by $\mathrm{Ag}^{+} / \mathrm{Cu}^{2+} / \mathrm{S}_{2} \mathrm{O}_{8}{ }^{2-}$ in water. To obviate the formation of $\mathbf{6 a}$ the reaction was performed in other solvents, such as DMF, $\mathrm{AcOH}$ or $\mathrm{MeOH}$ but it proved to be slower with the formation of complex mixtures (Table 2, entry 9 to 10) or incomplete when $\mathrm{MeOH}$ was used (Table 2, entry 11). When the reaction was performed in $\mathrm{AcOH} / \mathrm{H}_{2} \mathrm{O}$ (Table 2, entry 12) in addition to compound $\mathbf{4 a}$ and $\mathbf{6 a}$, compound 7 was also identified in $26 \%$ by NMR (Supplementary Figure S1) [50]. Since the reaction proved to be unsuccessful when performed in organic solvents, we decided to optimize the results attained in entry 8 by increasing the amount of catalyst and oxidant (Table 2, entry 13). Despite of the higher conversion observed, the increased load of persulfate also doubled the conversion to 6a. Being aware of the synergetic effect of copper in decarboxylation reactions, $\mathrm{CuSO}_{4}$ was applied to our system [38,40]. The use of 
catalytic amounts of $\mathrm{CuSO}_{4}$ with an excess of oxidant (3 equiv., Table 2, entry 14) lead to discouraging results. However, with 1 equivalent of $\mathrm{CuSO}_{4}$ the conversion of the product increased to $76 \%(89 \%$ based on the recovered starting material, Table 2, entry 15) despite the formation of 6 a. Increasing the temperature to $60^{\circ} \mathrm{C}$ lead to a complete reaction in $0.5 \mathrm{~h}$ as a mixture of compound $4 \mathbf{a}$ and 6a (Table 2, entry 16). Only by inverting the addition of the reagents and making the arginine derivative react first with $\mathrm{CuSO}_{4}$, the formation of $\mathbf{6 a}$ was suppressed and compound $4 \mathbf{a}$ was isolated in $72 \%$ yield (Table 2 , entry 17).

Table 2. Screening and results for the oxidative decarboxylation of $N^{\alpha}$-benzoyl-L-arginine derivatives (3a).

\begin{tabular}{|c|c|c|c|c|c|c|c|c|c|}
\hline Entry & Oxidant & $\begin{array}{l}\text { Additive } \\
\text { (equiv.) }\end{array}$ & Solvent & $\mathrm{T}\left({ }^{\circ} \mathrm{C}\right)$ & $\begin{array}{l}\text { Time } \\
\text { (h) }\end{array}$ & $\begin{array}{c}\text { (3a) } \\
\text { Relative } \\
\text { Amount } \\
(\%)^{a}\end{array}$ & $\begin{array}{c}\text { (4a) } \\
\text { Relative } \\
\text { Amount } \\
(\%)^{a}\end{array}$ & $\begin{array}{c}\text { (6a) } \\
\text { Relative } \\
\text { Amount } \\
(\%)^{a}\end{array}$ & $\begin{array}{c}(7) \\
\text { Relative } \\
\text { Amount } \\
(\%)^{a}\end{array}$ \\
\hline 1 & $\mathrm{DIB} / \mathrm{I}_{2}(2: 0.5)$ & - & $\mathrm{CH}_{2} \mathrm{Cl}_{2}$ & r.t. & 48 & $>90$ & vestigial & - & - \\
\hline $2^{f}$ & $\mathrm{DIB} / \mathrm{I}_{2}(2: 0.5)$ & - & DMF & r.t. & 18 & 100 & - & - & - \\
\hline 3 & $\mathrm{DIB} / \mathrm{I}_{2}(4: 1)$ & - & $\mathrm{CH}_{3} \mathrm{CN}$ & reflux & 56 & $>90$ & vestigial & - & - \\
\hline $4^{\mathrm{f}}$ & $\mathrm{DIB} / \mathrm{I}_{2}(4: 1)$ & - & $\mathrm{CH}_{2} \mathrm{Cl}_{2}$ & r.t. & 1.5 & 100 & - & - & - \\
\hline 5 & $\mathrm{DIB} / \mathrm{I}_{2}(4: 1)$ & - & $\mathrm{CH}_{2} \mathrm{Cl}_{2}$ & reflux & 48 & 92 & 8 & - & - \\
\hline $6^{g}$ & $\mathrm{DIB} / \mathrm{I}_{2}(4: 1)$ & - & DMSO & r.t. & 48 & - & - & - & - \\
\hline $7^{\mathrm{f}}$ & $\mathrm{DIB} / \mathrm{I}_{2}(2: 0.5)$ & - & $\begin{array}{c}\mathrm{AcOH} / \mathrm{CH}_{2} \mathrm{Cl}_{2} \\
(3: 1)\end{array}$ & reflux & 72 & - & $59^{e}$ & - & - \\
\hline $8^{b}$ & $\begin{array}{c}\mathrm{Ag}(\mathrm{I}) / \mathrm{S}_{2} \mathrm{O}_{8}{ }^{2-} \\
(0.1: 1.2)\end{array}$ & - & $\mathrm{H}_{2} \mathrm{O}$ & r.t. & 3 & 53 & 39 & 8 & - \\
\hline $9^{b, g}$ & $\begin{array}{c}\mathrm{Ag}(\mathrm{I}) / \mathrm{S}_{2} \mathrm{O}_{8}{ }^{2-} \\
(0.2: 1.2)\end{array}$ & - & DMF & r.t. & $>24$ & - & - & - & - \\
\hline $10^{\mathrm{b}, \mathrm{g}}$ & $\begin{array}{c}\mathrm{Ag}(\mathrm{I}) / \mathrm{S}_{2} \mathrm{O}_{8}{ }^{2-} \\
(0.15: 1.2)\end{array}$ & - & $\mathrm{AcOH}$ & r.t. & 96 & - & - & - & - \\
\hline $11^{\mathrm{b}, \mathrm{f}}$ & $\begin{array}{c}\mathrm{Ag}(\mathrm{I}) / \mathrm{S}_{2} \mathrm{O}_{8}{ }^{2-} \\
(0.15: 1.5)\end{array}$ & - & $\mathrm{MeOH}$ & r.t. & 48 & 100 & - & - & - \\
\hline $12^{b}$ & $\begin{array}{c}\mathrm{Ag}(\mathrm{I}) / \mathrm{S}_{2} \mathrm{O}_{8}{ }^{2-} \\
(0.15: 1.5)\end{array}$ & - & $\begin{array}{c}\mathrm{AcOH}: \mathrm{H}_{2} \mathrm{O} \\
(1: 1)\end{array}$ & r.t. & 20 & - & 35 & 39 & 26 \\
\hline $13^{c}$ & $\begin{array}{c}\mathrm{Ag}(\mathrm{I}) / \mathrm{S}_{2} \mathrm{O}_{8}{ }^{2-} \\
(0.15: 1.5)\end{array}$ & - & $\mathrm{H}_{2} \mathrm{O}$ & r.t. & 3 & - & 69 & 17 & 11 \\
\hline $14^{g}$ & $\begin{array}{c}\mathrm{Ag}(\mathrm{I}) / \mathrm{S}_{2} \mathrm{O}_{8}{ }^{2-} \\
(0.15: 3)\end{array}$ & $\begin{array}{c}\mathrm{CuSO}_{4} \\
(0.2)\end{array}$ & $\mathrm{H}_{2} \mathrm{O}$ & r.t. & 3 & - & - & - & - \\
\hline $15^{c}$ & $\begin{array}{c}\mathrm{Ag}(\mathrm{I}) / \mathrm{S}_{2} \mathrm{O}_{8}{ }^{2-} \\
(0.15: 1.5)\end{array}$ & $\underset{\mathrm{CuSO}_{4}}{(1)}$ & $\mathrm{H}_{2} \mathrm{O}$ & r.t. & 3 & - & 89 & 7 & 4 \\
\hline 16 & $\begin{array}{c}\mathrm{Ag}(\mathrm{I}) / \mathrm{S}_{2} \mathrm{O}_{8}{ }^{2-} \\
(0.15: 1.5)\end{array}$ & $\mathrm{CuSO}_{4}$ & $\mathrm{H}_{2} \mathrm{O}$ & 60 & 0.5 & - & 83 & 8 & 5 \\
\hline $17^{\mathrm{d}}$ & $\begin{array}{c}\mathrm{Ag}(\mathrm{I}) / \mathrm{S}_{2} \mathrm{O}_{8}{ }^{2-} \\
(0.15: 1.5)\end{array}$ & $\underset{\mathrm{CuSO}}{4}$ & $\mathrm{H}_{2} \mathrm{O}$ & 60 & 0.5 & - & $72^{\mathrm{e}}$ & - & - \\
\hline
\end{tabular}

The reaction was then extended to compounds $\mathbf{3 b}-\mathbf{3 h}$. Complex mixtures were obtained with compounds $\mathbf{3 c}, \mathbf{3 d}, \mathbf{3 e}$ and $\mathbf{3} \mathbf{f}$ all bearing moieties able to be involved in radical reactions. Positive results were only achieved for $4 \mathrm{~b}$ and $\mathbf{4 h}$ although, in the latter, the reaction yield was low due to incomplete reaction (Table 3). As expected, in this last case it was observed by HPLC-ESI-MS the presence of two peaks, which would correspond to the two diastereomers of $4 \mathrm{~h}$ as a result of the racemization at the C-2 position of the pyrrolidine ring being formed (Supplementary Figure S2). However, for our surprise analysis of $3 \mathrm{~h}$ also shows two peaks in the HPLC-ESI-MS instead of only one (Supplementary Figure S3). These peaks co-eluted with the two diastereomers of 4 h (Supplementary Figure S2a). This means that racemization occurs not only during the oxidative decarboxylation but also during the formation of the dipeptide.

Next we turned our attention to the alternative strategy involving the oxidative decarboxylation of carbamimidoyl-L-proline (2) using the same oxidative system $\left(\mathrm{AgNO}_{3} /\left(\mathrm{NH}_{4}\right)_{2} \mathrm{~S}_{2} \mathrm{O}_{8}\right)$. 
Table 3. Scope of substrates for the oxidative decarboxylation of L-arginine derivatives (3) and carbamimidoyl-L-proline (2).

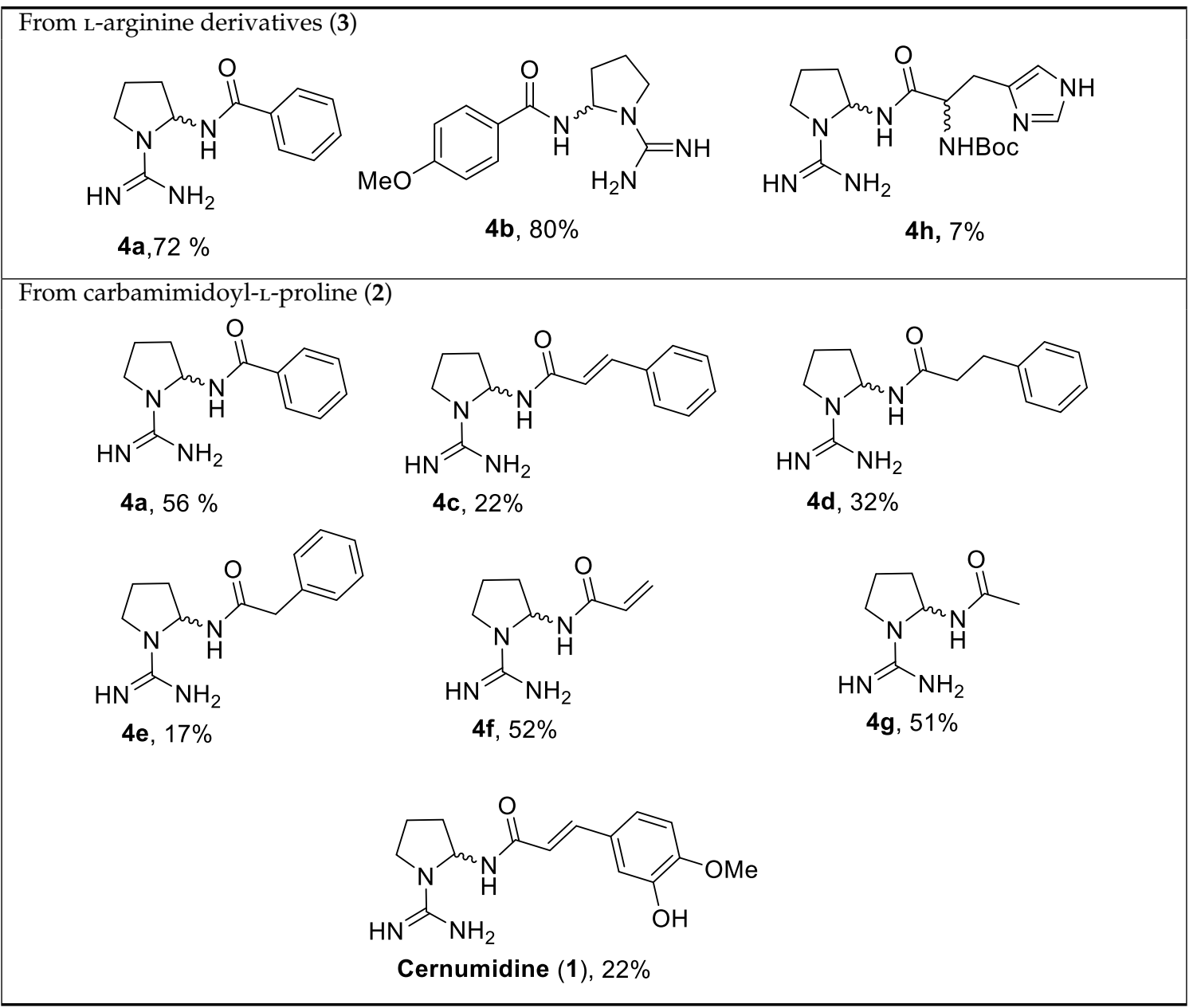

\subsection{Studies on the Oxidative Decarboxylation of Carbamimidoyl-L-proline (2)}

We believe that this approach proceeds through a mechanism like the one proposed for the arginine derivatives. As in the latter, the oxidative decarboxylation of 2 generates an iminium ion (8) that will be trapped by benzamide to form $4 \mathbf{a}$ (Scheme 3). Here, once again, the reaction conditions will play a crucial role in the reaction outcome. The iminium (8) can be trapped by water to the hemiaminal (9) that can be further oxidized to the pyrrolidone (10) or be cleaved to the aldehyde (11). Screening of the reaction conditions is presented in (Table 4). Initially, our attention was devoted to the solubility of benzamide, and therefore the first assays (Table 4, entries 1-6) were carried out in organic solvents, but none proved to be suitable to afford the desired product $4 \mathbf{a}$. Moreover, in all these assays it was possible to observe in the NMR spectra (not isolated and not quantified) the formation of pyrrolidone (10) as the major product and hemiaminal (9) as a minor product (Supplementary Figure S4, data in accordance with literature [24]). Next, considering the solubility of 2 we decided to fully adopt the conditions used for the decarboxylation of 3 by using water as solvent and $\mathrm{CuSO}_{4}$ as a co-catalyst. In these conditions (Table 4, entries 7-8) the formation of $\mathbf{1 0}$ was supressed entirely and for the first time, the formation of the desired product 4 a was observed. 

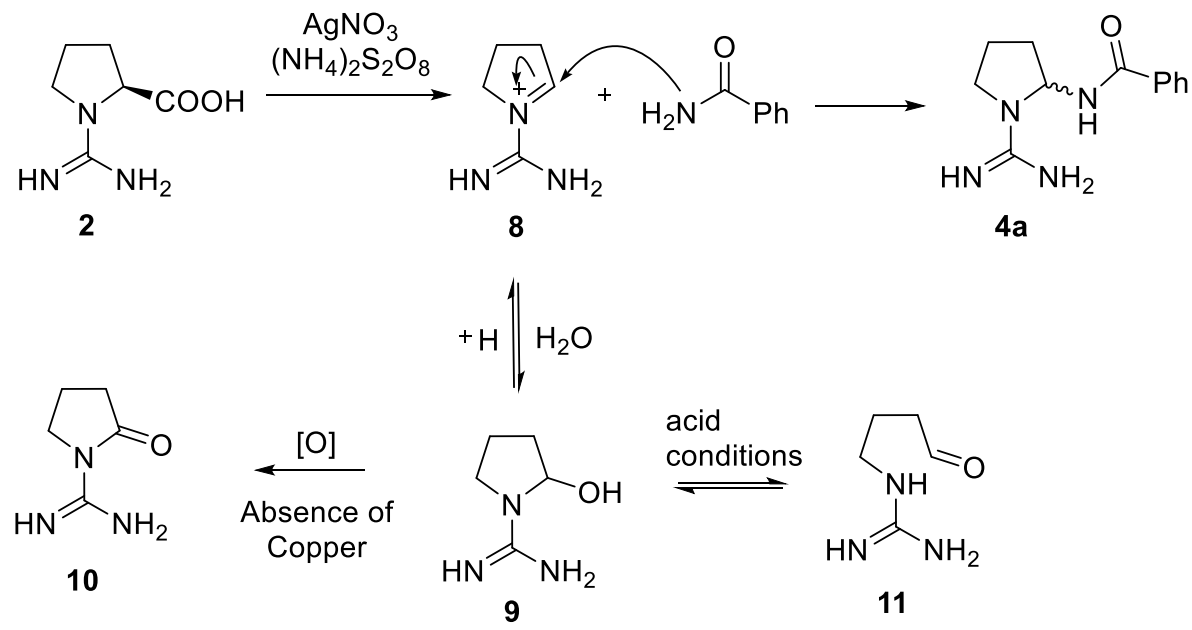

Scheme 3. Proposed mechanism for the oxidative decarboxylation of carbamimidoyl-L-proline (2) to 2-aminopyrrolidine-1-carboxamidine (4a).

Curiously, the lower reaction time and formation of product (Table 4, entry 8) contrasts directly with the result observed in entry 7 where only hemiaminal (9) was formed during the reaction, which indicates that the temperature is crucial for the reaction outcome. Afterwards, we investigated the role of copper in the formation of $\mathbf{1 0}$ (Table 4, entries 9 and 10). In the absence of any nucleophile when the reaction is carried out without copper (Table 4, entry 9) compound $\mathbf{1 0}$ was observed as the main product, whereas in the presence of copper the major product was the hemiaminal (9) (Table 4, entry 10), which suggests that copper prevents the oxidation of $\mathbf{9}$. Once the formation of $\mathbf{1 0}$ was suppressed, we turned our attention to finding strategies that would avoid the formation 9 . We started by changing the reaction solvent to $\mathrm{MeOH}$ (Table 4, entry 11) and ACN (Table 4, entry 12) but in the former, the reaction did not occur and in the latter, the yield of $4 \mathbf{a}$ was low. Since the reaction proved to be successful only in water, we investigate if the conversion of the hemiaminal (9) into the iminium (8) was possible. We anticipated that under acidic conditions it should be possible to favour the formation of 8 from 9. By adding catalytic amounts of $p$-toluenesulfonic acid ( $p$ - $\mathrm{TsOH})$ to the reaction (Table 4, entry 13) we only observed the formation of $4 \mathbf{a}$. However, we were not able to separate the desired product from the $p-\mathrm{TsOH}$. Nonetheless, inspired by the previous result, we decided to use an acid resin (Amberlyst 15) that was easily removed from the reaction mixture and allowed the isolation of the desired product in 56\% yield (Table 4, entry 14). With these conditions, we were able to observe an inverse correlation between the yield and reaction time. By increasing the reaction time, the reaction yield decreases (Table 4, entries 15-17). Reducing the reaction time (to $6 \mathrm{~h}$ ) the yield also decreased (Table 4, entry 18) and the product $4 \mathbf{a}$ was obtained in only $18 \%$ yield. These findings suggest that the reaction outcome has close relation between the reactivity of the reagents and product stability. That was confirmed by mixing 4a and Amberlyst 15 in water at $60^{\circ} \mathrm{C}$ for $24 \mathrm{~h}$, which results in a 1:1 mixture of hemiaminal (9) and 4a. However, despite the product stability, we believed that other factors might justify the low yield of the reaction. In all the assays that were performed the yield of the reaction contrasts with the information obtained by the NMR analysis of the reaction mixture. The NMR always led us to conceive that we were in the presence of a simple mixture of the desired product and the correspondent benzamide. Thus, knowing already that degradation of product occurs during the reaction, we decided to analyse the decarboxylation step of our reaction. For that purpose, the reaction mixture attained (Table 4, entry 10) was analysed by HPLC-ESI-MS (Supplementary Figure S5). With a retention time of $4.1 \mathrm{~min}$, it was possible to identify compound 9 by the peak at $\mathrm{m} / \mathrm{z} 130$ that correspond to the $[\mathrm{M}+\mathrm{H}]^{+}$and the pyrrolidone (10) with the peaks at $\mathrm{m} / z 128$ and $\mathrm{m} / z 146$ that correspond to the $[\mathrm{M}+\mathrm{H}]^{+}$and $\left[\mathrm{M}+\mathrm{H}+\mathrm{H}_{2} \mathrm{O}\right]^{+}$, respectively. With a retention time of $4.5 \mathrm{~min}$ the peaks at $m / z 156$ and $m / z 313$ in negative mode correspond to the ions $[\mathrm{M}-\mathrm{H}]^{-}$and $[2 \mathrm{M}-\mathrm{H}]^{-}$of the starting material 2 which are in accordance in positive mode with the peaks at $m / z 158$ and $\mathrm{m} / \mathrm{z} 315$. 
The LC-MS indicates the presence of other compounds which shows the lability of the intermediates involved and indicates that, even prior to the formation of our product, the outcome of our reaction is being affected by a variety of divergent pathways. This factor, combined with the instability of the products, may explain the low to moderate yields obtained in this approach.

Table 4. Screening and results for the oxidative decarboxylation of carbamimidoyl-L-proline (2) and trapping the iminium intermediate with benzamide.

\begin{tabular}{|c|c|c|c|c|c|c|c|c|}
\hline Entry & Oxidant & Additive & Solvent & $\mathrm{T}\left({ }^{\circ} \mathrm{C}\right)$ & Time (h) & $(9)^{a}$ & $(10)^{a}$ & $\begin{array}{c}(4 a) \\
\text { Yield (\%) }\end{array}$ \\
\hline 1 & $\begin{array}{c}\mathrm{Ag}(\mathrm{I}) / \mathrm{S}_{2} \mathrm{O}_{8}{ }^{2-} \\
(0.3: 3)\end{array}$ & - & $\mathrm{ACN} / \mathrm{H}_{2} \mathrm{O}$ & r.t. & 5.5 & $\checkmark^{\mathrm{b}}$ & $\checkmark^{a}$ & - \\
\hline 2 & $\begin{array}{c}\mathrm{Ag}(\mathrm{I}) / \mathrm{S}_{2} \mathrm{O}_{8}{ }^{2-} \\
(0.3: 3)\end{array}$ & - & $\mathrm{ACN} / \mathrm{H}_{2} \mathrm{O}$ & r.t. & 72 & $\checkmark^{\mathrm{b}}$ & $\checkmark^{\mathrm{a}}$ & - \\
\hline 3 & $\begin{array}{c}\mathrm{Ag}(\mathrm{I}) / \mathrm{S}_{2} \mathrm{O}_{8}{ }^{2-} \\
(0.3: 3)\end{array}$ & - & $\mathrm{AcOH}$ & r.t. & 72 & $\checkmark^{\mathrm{b}}$ & $\checkmark^{a}$ & - \\
\hline 4 & $\begin{array}{c}\mathrm{Ag}(\mathrm{I}) / \mathrm{S}_{2} \mathrm{O}_{8}{ }^{2-} \\
(0.3: 3)\end{array}$ & - & DMA & r.t. & 72 & $\checkmark^{\mathrm{b}}$ & $\checkmark^{a}$ & - \\
\hline 5 & $\begin{array}{c}\mathrm{Ag}(\mathrm{I}) / \mathrm{S}_{2} \mathrm{O}_{8}{ }^{2-} \\
(0.3: 3)\end{array}$ & - & $\mathrm{ACN} / \mathrm{H}_{2} \mathrm{O}$ & 80 & 6 & $\checkmark^{b}$ & $\checkmark^{a}$ & - \\
\hline 6 & $\begin{array}{c}\mathrm{Ag}(\mathrm{I}) / \mathrm{S}_{2} \mathrm{O}_{8}{ }^{2-} \\
(0.3: 3)\end{array}$ & - & DMA & r.t. & 6 & - & - & - \\
\hline 7 & $\begin{array}{c}\mathrm{Ag}(\mathrm{I}) / \mathrm{S}_{2} \mathrm{O}_{8}{ }^{2-} \\
(0.15: 1)\end{array}$ & $\mathrm{CuSO}_{4}$ & $\mathrm{H}_{2} \mathrm{O}$ & r.t. & 15 & $\checkmark^{a}$ & - & - \\
\hline 8 & $\begin{array}{c}\mathrm{Ag}(\mathrm{I}) / \mathrm{S}_{2} \mathrm{O}_{8}{ }^{2-} \\
(0.15: 1)\end{array}$ & $\mathrm{CuSO}_{4}$ & $\mathrm{H}_{2} \mathrm{O}$ & reflux & 2 & $\checkmark^{a}$ & - & $\checkmark^{b}$ \\
\hline $9^{d}$ & $\begin{array}{c}\mathrm{Ag}(\mathrm{I}) / \mathrm{S}_{2} \mathrm{O}_{8}{ }^{2-} \\
(0.15: 1)\end{array}$ & & $\mathrm{H}_{2} \mathrm{O}$ & reflux & 2 & $\checkmark^{\mathrm{b}}$ & $\checkmark^{a}$ & - \\
\hline $10^{\mathrm{d}}$ & $\begin{array}{c}\mathrm{Ag}(\mathrm{I}) / \mathrm{S}_{2} \mathrm{O}_{8}{ }^{2-} \\
(0.15: 1)\end{array}$ & $\mathrm{CuSO}_{4}$ & $\mathrm{H}_{2} \mathrm{O}$ & reflux & 2 & $\sqrt{ }^{\mathrm{a}}$ & - & - \\
\hline $11^{\mathrm{e}}$ & $\begin{array}{c}\mathrm{Ag}(\mathrm{I}) / \mathrm{S}_{2} \mathrm{O}_{8}{ }^{2-} \\
(0.15: 1)\end{array}$ & $\mathrm{CuSO}_{4}$ & $\mathrm{MeOH}$ & reflux & 16 & - & - & - \\
\hline 12 & $\begin{array}{c}\mathrm{Ag}(\mathrm{I}) / \mathrm{S}_{2} \mathrm{O}_{8}{ }^{2-} \\
(0.15: 1)\end{array}$ & $\mathrm{CuSO}_{4}$ & $\mathrm{ACN}$ & reflux & 6 & - & $\checkmark^{b}$ & 9 \\
\hline 13 & $\begin{array}{c}\mathrm{Ag}(\mathrm{I}) / \mathrm{S}_{2} \mathrm{O}_{8}{ }^{2-} \\
(0.15: 1)\end{array}$ & $\begin{array}{c}\mathrm{CuSO}_{4} / \\
\mathrm{TsOH} \\
(20 \mathrm{~mol} \%)\end{array}$ & $\mathrm{H}_{2} \mathrm{O}$ & reflux & 16 & - & - & $\checkmark^{a}$ \\
\hline 14 & $\begin{array}{c}\mathrm{Ag}(\mathrm{I}) / \mathrm{S}_{2} \mathrm{O}_{8}{ }^{2-} \\
(0.15: 1)\end{array}$ & $\begin{array}{c}\mathrm{CuSO}_{4} / \\
\text { Amberlite } 15\end{array}$ & $\mathrm{H}_{2} \mathrm{O}$ & $60{ }^{\circ} \mathrm{C}$ & 16 & - & - & $56^{c}$ \\
\hline 15 & $\begin{array}{c}\mathrm{Ag}(\mathrm{I}) / \mathrm{S}_{2} \mathrm{O}_{8}{ }^{2-} \\
(0.15: 1)\end{array}$ & $\begin{array}{c}\mathrm{CuSO}_{4} / \\
\text { Amberlite } 15\end{array}$ & $\mathrm{H}_{2} \mathrm{O}$ & $60^{\circ} \mathrm{C}$ & 24 & - & - & $50^{c}$ \\
\hline 16 & $\begin{array}{c}\mathrm{Ag}(\mathrm{I}) / \mathrm{S}_{2} \mathrm{O}_{8}{ }^{2-} \\
(0.15: 1)\end{array}$ & $\begin{array}{c}\mathrm{CuSO}_{4} / \\
\text { Amberlite } 15\end{array}$ & $\mathrm{H}_{2} \mathrm{O}$ & $60{ }^{\circ} \mathrm{C}$ & 48 & - & - & $33^{c}$ \\
\hline 17 & $\begin{array}{c}\mathrm{Ag}(\mathrm{I}) / \mathrm{S}_{2} \mathrm{O}_{8}{ }^{2-} \\
(0.15: 1)\end{array}$ & $\begin{array}{c}\mathrm{CuSO}_{4} / \\
\text { Amberlite } 15\end{array}$ & $\mathrm{H}_{2} \mathrm{O}$ & $60^{\circ} \mathrm{C}$ & 72 & - & - & $22^{c}$ \\
\hline 18 & $\begin{array}{c}\mathrm{Ag}(\mathrm{I}) / \mathrm{S}_{2} \mathrm{O}_{8}{ }^{2-} \\
(0.15: 1)\end{array}$ & $\begin{array}{c}\mathrm{CuSO}_{4} / \\
\text { Amberlite } 15\end{array}$ & $\mathrm{H}_{2} \mathrm{O}$ & $60^{\circ} \mathrm{C}$ & 6 & - & - & $18^{c}$ \\
\hline
\end{tabular}

${ }^{a}$ Major product; ${ }^{\mathrm{b}}$ Minor product; ${ }^{\mathrm{c}} \mathrm{AgNO}_{3}$ (0.15 equiv); $\mathrm{CuSO}_{4}$ (1 equiv), $\left(\mathrm{NH}_{4}\right)_{2} \mathrm{~S}_{2} \mathrm{O}_{8}$ (1 equiv), Amberlite 15 (20\% $w / w)$ in water $(1 \mathrm{M})$ at $60{ }^{\circ} \mathrm{C}$ overnight $(16-18 \mathrm{~h}) ;{ }^{\mathrm{d}}$ Absence of benzamide; ${ }^{\mathrm{e}}$ No reaction.

Afterwards, to examine the scope of this decarboxylating coupling reaction, various amides were reacted under the optimized reaction conditions. Remarkably, at this time we were able to achieve several 2-aminopyrrolidine-1-carboxamidine derivatives (Table 3 ) as compounds $\mathbf{4 c}$, $\mathbf{4 d}$, and $\mathbf{4 e}$ that were not attainable by the method involving the oxidative decarboxylation of the $N^{\alpha}$-acyl-L-arginine derivatives 3c, 3f, and 3g. Gladly, although in its racemic form, we were able to synthesize for the first time the cernumidine alkaloid (1) in $22 \%$ yield from reaction of compound 2 with acetylated isoferulic amide.

To fully explore the scope of the reaction, sulfinate salts were tested as nucleophiles without success. We believe that the sulfinate salts are even more prone to retro-elimination of the nucleophile, 
and therefore the products were not stable under the acidic conditions of the reaction. The use of other nucleophiles is limited by the stability of the product being formed and the acidic conditions used, which is only compatible with non-basic nucleophiles.

\section{Materials and Methods}

All the reagents and solvents were obtained commercially (Merck KGaA, Darmstadt, Germany), and these were used without further purification. The solvents used were dried using current laboratory techniques. Thin-layer chromatography (TLC) was carried out on aluminium backed Kieselgel 60 F254 silica gel plates (Merck KGaA, Darmstadt, Germany). Plates were visualized under UV light (254 and/or $366 \mathrm{~nm}$ ). Reversed phase column chromatography was carried out on silica gel LiChoroprep RP-18 (40-63 m, Merck KGaA, Darmstadt, Germany). Ultraviolet spectroscopy (UV) was recorded on a Thermo Corporation spectrophotometer (Waltham, MA, USA), Helius $\gamma$, on quartz cell support. Absorption spectrum measurements were made in the range of 190-320 nm. Infrared spectroscopy (IR) was recorded on a PerkinElmer Spectrum Two (Waltham, MA, USA) in the range of $4000-400 \mathrm{~cm}^{-1} .{ }^{1} \mathrm{H}$ and ${ }^{13} \mathrm{C}$ NMR spectra were recorded on a Brucker ARX400 (Billerica, MA, USA) at 400 and $101 \mathrm{MHz}$, respectively. Chemical shifts are reported in parts per million (ppm, $\delta$ units). The following NMR abbreviations are used: $\mathrm{s}=$ singlet, $\mathrm{d}=$ doublet, $\mathrm{t}=$ triplet, $\mathrm{q}=$ quartet, $\mathrm{m}=$ multiplet, brs = broad singlet . The relative amount of each compound presented in Table 2 was based on the analysis of the crude NMR, where the individualized integral of the H-2 proton of each compound was used. HPLC-ESI-MS was acquired on an Agilent 1200 Series LC (Santa Clara, CA, USA) with a quaternary pump, ALS, TCC, DAD, and Agilent G6130B LC/MSD (Santa Clara, CA, USA) with API-ES source, in FIA mode or LC mode with a Zorbax-SB-C18 $(4.6 \times 150 \mathrm{~mm}, 5 \mu \mathrm{m}$, Agilent, Santa Clara, CA, USA) (Porto University) and in a QqTOF Impact IITM mass spectrometer (Bruker Daltonics, Billerica, MA, USA) operating in the high resolution mode. Samples were analyzed by flow injection analysis (FIA) using an isocratic gradient $50 \mathrm{~A}: 50 \mathrm{~B}$ of $0.1 \%$ formic acid in water (A) and $0.1 \%$ of formic acid in acetonitrile (B), at a flow rate of $10 \mu \mathrm{L} \cdot \mathrm{min}^{-1}$ over $15 \mathrm{~min}$. Calibration of the TOF analyzer was performed with a calibrant solution of sodium formate $10 \mathrm{mM}$. The full scan mass spectra were acquired over a mass range of 50-1000 m/z, at a spectra rate of $0.2 \mathrm{~Hz}$. Data was processed using Data Analysis 4.2 software (Lisbon University, Bruker, Billerica, MA, USA, 2015). ESI-HRMS (Electrospray ionization-high resolution mass spectrometry) was performed in an LTQ Orbitrap XLTM mass spectrometer (Thermo Fischer Scientific, Bremen, Germany) controlled by LTQ Tune Plus 2.5.5 and Xcalibur 2.1.0. The capillary voltage of the electrospray ionization (ESI) was set to $3100 \mathrm{~V}$. The capillary temperature was $275^{\circ} \mathrm{C}$. The sheath gas flow rate (nitrogen) was set to 6 (arbitrary unit as provided by the software settings). The capillary voltage was $49 \mathrm{~V}$ and the tube lens voltage $130 \mathrm{~V}$. The description of these spectra follows the format: mass $(\mathrm{m} / \mathrm{z})$; attribution in the molecule. The designation $[\mathrm{M}+\mathrm{H}]^{+}$always corresponds to the molecular ion of interest.

\subsection{General Procedure for the Synthesis of Arginine Derivatives}

\section{Method A (3a, 3c, 3e-3g)}

To a solution of the corresponding carboxylic acid in toluene (volume to make a $0.5 \mathrm{M}$ solution of substrate), $\mathrm{SOCl}_{2}$ (5 equiv.) was slowly added and the reaction was stirred at reflux temperature for $1 \mathrm{~h}$. Then, volatiles were removed under reduced pressure to afford the desired acyl chloride.

To a round-bottom flask charged with a solution of L-Arginine in water (volume to make a $0.2 \mathrm{M}$ solution of substrate) $\mathrm{Na}_{2} \mathrm{CO}_{3}$ (2 equiv.) was added. The solution was cooled at $0{ }^{\circ} \mathrm{C}$ and the acyl chloride (1.2 equiv.) was added portion wise. The reaction mixture was stirred at $0{ }^{\circ} \mathrm{C}$ for $10 \mathrm{~min}$ and then at r.t. until complete consumption of the starting material ( 24 to $72 \mathrm{~h}$ ). After that, the mixture was acidified with a solution of $\mathrm{HCl} 3 \mathrm{M}$ to $\mathrm{pH} 1$, and the aqueous phase was washed $3 \times$ with DMC. The resulting aqueous phase was then basified with $\mathrm{NaOH} 4 \mathrm{M}$ to $\mathrm{pH}$, evaporated until dryness and 
purified by using RP18 column chromatography. The collected fractions were analyzed by UV-Vis and were then combined according to the obtained UV-spectra to afford the desired product.

Method B (3b, 3d and 3h)

To a solution of the correspondent carboxylic acid (1.2 equiv.) in dry DCM (volume to make a $0.5 \mathrm{M}$ solution of substrate) CDI (1.5 equiv.) was added, and the reaction was stirred until complete consumption of the starting material (TLC, DCM/MeOH 19:1). Then, the reaction mixture was concentrated under vacuum and to the attained residue a solution of the arginine derivative (1 equiv.) in DMF (volume to make a $0.5 \mathrm{M}$ solution of substrate) and DMAP (0.1 equiv.) were added and the reaction was stirred at $80^{\circ} \mathrm{C}$ until complete consumption of the starting material (TLC, $\mathrm{DCM} / \mathrm{MeOH} / \mathrm{H}_{2} \mathrm{O}$ 13:7:1). After the consumption of the starting material, the solvent was removed under reduced pressured and the reaction mixture was purified by RP-18 column chromatography. The collected fractions were analyzed by UV-vis and combined according to the obtained UV-spectra.

Compound 3a [51]. Following the general procedure A, from $4 \mathrm{~g}$ of L-Arginine compound 3a was obtained in $47 \%$ yield; m.p. $285-288^{\circ} \mathrm{C}$. IV $($ ATR $) v_{\text {máx }}\left(\mathrm{cm}^{-1}\right) 3200,1677,1615,1592 .{ }^{1} \mathrm{H}$ RMN $\left(400 \mathrm{MHz}, \mathrm{D}_{2} \mathrm{O}\right) \delta 7.80\left(\mathrm{~d}, J=7.7 \mathrm{~Hz}, 2 \mathrm{H}, \mathrm{H}-3^{\prime}\right.$ and $\left.\mathrm{H}-7^{\prime}\right), 7.62\left(\mathrm{t}, J=7.2 \mathrm{~Hz}, 1 \mathrm{H}, \mathrm{H}-5^{\prime}\right), 7.54(\mathrm{t}, J=7.6 \mathrm{~Hz}$, $2 \mathrm{H}, \mathrm{H}-4^{\prime}$ and $\left.\mathrm{H}-6^{\prime}\right), 4.41(\mathrm{dd}, J=8.1,5.1 \mathrm{~Hz}, 1 \mathrm{H}, \mathrm{H}-2), 3.23(\mathrm{t}, J=6.8 \mathrm{~Hz}, 2 \mathrm{H}, \mathrm{H}-5), 2.07-1.92(\mathrm{~m}, 1 \mathrm{H}$, $\mathrm{H}-3 \mathrm{a}), 1.91-1.77$ (m, 1H, H-3b), 1.75-1.63 (m, 2H, H-4). ${ }^{13} \mathrm{C}$ NMR (101 MHz, $\left.\mathrm{D}_{2} \mathrm{O}\right) \delta 178.22(\mathrm{C}-1), 169.94$ $\left(\mathrm{C}-1^{\prime}\right), 156.62$ (C-6), 133.42 (C-2'), 132.06 (C-5'), 128.64 (C-3' e H-7'), 126.97 (C-4' e H-6'), 55.04 (C-2), 40.58 (C-5), 28.95 (C-3), 24.50 (C-5).

Compound $\mathbf{3 b}$. Following the general procedure $\mathrm{B}$, from $1 \mathrm{~g}$ of $\mathrm{L}$-Arginine compound $\mathbf{3} \mathbf{b}$ was obtained in $59 \%$ yield. m.p. $90-93{ }^{\circ} \mathrm{C}$. IR (ATR) $v_{\text {máx }}\left(\mathrm{cm}^{-1}\right) 3160,1604,1543,1501,1393,1252 .{ }^{1} \mathrm{H}$ RMN $(400 \mathrm{MHz}$, $\left.\mathrm{D}_{2} \mathrm{O}\right) \delta 7.79\left(\mathrm{~d}, J=8.6 \mathrm{~Hz}, 2 \mathrm{H}, \mathrm{H}-3^{\prime}\right.$ e $\left.\mathrm{H}-7^{\prime}\right), 7.05\left(\mathrm{~d}, J=8.7 \mathrm{~Hz}, 2 \mathrm{H}, \mathrm{H}-4^{\prime}\right.$ e $\left.\mathrm{H}-6^{\prime}\right), 4.39(\mathrm{dd}, J=7.8$, $5.2 \mathrm{~Hz}, 1 \mathrm{H}, \mathrm{H}-2), 3.88$ (s, 3H, OMe), $3.22(\mathrm{t}, J=6.7 \mathrm{~Hz}, 2 \mathrm{H}, \mathrm{H}-5), 2.05-1.91$ (m, 1H, H-3a), 1.89-1.76 (m, 1H, H-3b), 1.74-1.61 (m, 2H, H-4). ${ }^{13} \mathrm{C}$ NMR (101 MHz, D $\left.2 \mathrm{O}\right) \delta 178.72$ (C-1), 169.30 (C-1'), 161.91 $\left(\mathrm{C}-5^{\prime}\right), 156.62(\mathrm{C}-6), 129.09$ (C-3' e C-7'), $125.72\left(\mathrm{C}-2^{\prime}\right), 113.88$ (C-4' e C-6'), $55.41(\mathrm{OMe}), 55.14$ (C-2), 40.63 (C-5), 28.87 (C-3), 24.55 (C-4). HRMS (ESI) $m / z$ calculated for $\mathrm{C}_{14} \mathrm{H}_{20} \mathrm{~N}_{4} \mathrm{O}_{4}\left[\mathrm{MH}^{+}\right.$]: 308.14846 ; Found: 308.14556.

Compound 3c [52]. Following the general procedure A, from $2 \mathrm{~g}$ of $\mathrm{L}$-Arginine compound $3 \mathbf{c}$ was obtained in 55\% yield. m.p. $190-192{ }^{\circ} \mathrm{C}$. IR $($ ATR $) v_{\operatorname{máx}}\left(\mathrm{cm}^{-1}\right) 3333,3161,3046,2944,1667,1567 .{ }^{1} \mathrm{H}$ RMN (400 MHz, CD $\left.{ }_{3} \mathrm{OD}\right)$ 8 7.54-7.44 (m, 3H, H-3' , H-5' e H-9'), 7.43-7.31 (m, 3H, H-6', H-7' e H-8'), $6.73\left(\mathrm{~d}, J=15.8 \mathrm{~Hz}, 1 \mathrm{H}, \mathrm{H}-2^{\prime}\right), 4.46(\mathrm{dd}, J=7.6,4.8 \mathrm{~Hz}, 1 \mathrm{H}, \mathrm{H}-2), 3.23(\mathrm{tt}, J=13.5,6.8 \mathrm{~Hz}, 2 \mathrm{H}, \mathrm{H}-5)$, 2.04-1.91 (m, 1H, H-3a), 1.89-1.76 (m, 1H, H-3b), 1.75-1.62 (m, 2H, H-4). ${ }^{13} \mathrm{C}$ NMR (101 MHz, CD $\left.{ }_{3} \mathrm{OD}\right)$ $\delta 177.61$ (C-1), $166.61\left(\mathrm{C}-1^{\prime}\right), 157.30$ (C-6), $140.14\left(\mathrm{C}-3^{\prime}\right), 134.93$ (C-4'), 129.28 (C-7'), 128.45 (C-6' e C-8'), 127.48 (C-5' e C-9'), 120.83 (C-2'), 54.29 (C-2), 40.67 (C-5), 29.80 (C-3), 24.86 (C-4).

Compound 3d. Following the general procedure B, from $\mathrm{g}$ of $\mathrm{L}$-Arginine compound $\mathbf{3 d}$ was obtained in $55 \%$ yield. m.p. $112-115^{\circ} \mathrm{C}$. IR (ATR) $v_{\operatorname{máx}}\left(\mathrm{cm}^{-1}\right) 3400,2900,1638,1605,1573,1510,1394,1251 .{ }^{1} \mathrm{H}$ RMN (400 MHz, CD $\left.{ }_{3} \mathrm{OD}\right) \delta 7.38-7.27$ (m, 3H, H-3'e, H-5' e H-9'), 6.80 (d, J = 8.5 Hz, 2H, H-6' e H-8'), $6.48\left(\mathrm{~d}, J=15.7 \mathrm{~Hz}, 1 \mathrm{H}, \mathrm{H}-2^{\prime}\right), 4.36$ (dd, $\left.J=8.0,4.8 \mathrm{~Hz}, 1 \mathrm{H}, \mathrm{H}-2\right), 3.72(\mathrm{~s}, 3 \mathrm{H}, \mathrm{OMe}), 3.20-3.04(\mathrm{~m}, 2 \mathrm{H}$, H-5), 1.93-1.79 (m, 1H, H-3a), 1.77-1.64 (m, 1H, H-3b), 1.65-1.53 (m, 2H, H-4). ${ }^{13} \mathrm{C}$ NMR (101 MHz, $\left.\mathrm{CD}_{3} \mathrm{OD}\right) \delta 179.18$ (C-1), 168.46 (C-1'), 162.48 (C-7'), 158.71 (C-6), 141.32 (C-3'), 130.48 (C-5' e H-9'), 128.91 (C-4'), 119.70 (C-2'), 115.26 (C-6' e C-8'), 55.83 (OMe), 42.06 (C-5), 31.19 (C-3), 26.32 (C-4). HRMS (ESI) $\mathrm{m} / z$ calculated for $\mathrm{C}_{16} \mathrm{H}_{22} \mathrm{~N}_{4} \mathrm{O}_{4}[\mathrm{MH}]^{+}$: 334.16411; Found: 334.16135 .

Compound 3e. Following the general procedure A, from $0.5 \mathrm{~g}$ of L-Arginine compound $3 \mathbf{e}$ was obtained in $63 \%$ yield. m.p. $125-128^{\circ} \mathrm{C}$. IR (ATR) $v_{\text {máx }}\left(\mathrm{cm}^{-1}\right) 3258,3160,2969,2872,1633,1557,1394 .{ }^{1} \mathrm{H}$ RMN (400 MHz, $\mathrm{D}_{2} \mathrm{O}$ ) $\delta 7.35$ (t, J = 7.4 Hz, 2H, H-6' e H-8'), 7.31-7.22 (m, 3H, H-5', H-6' e H-9'), 4.05 (dd, $J=8.3,4.2 \mathrm{~Hz}, 1 \mathrm{H}, \mathrm{H}-2), 3.04-2.85$ (m, 4H, H-5 e H-3'), 2,63 (t, $\left.J=6.9 \mathrm{~Hz}, 2 \mathrm{H}, \mathrm{H}-2^{\prime}\right), 1.72-1.59(\mathrm{~m}, 1 \mathrm{H}$, H-3a), 1.56-1.43 (m, 1H, H-3b), 1.15 (p, J = 7.5 Hz, 2H, H-4). ${ }^{13} \mathrm{C}$ NMR $\left(101 \mathrm{MHz}, \mathrm{D}_{2} \mathrm{O}\right) \delta 178.55$ (C-1), 
$174.90\left(\mathrm{C}-1^{\prime}\right), 156.50(\mathrm{C}-6), 140.33\left(\mathrm{C}-4^{\prime}\right), 128.58$ (C-6' e C-8'), 128.49 (C-5' e C-9') 126.35 (C-7'), 54.32 (C-2), 40.54 (C-5), 37.24 (C-2'), 31.26 (C-3'), 28.69 (C-3), 24.12 (C-4). HRMS (ESI) $m / z$ calculated for $\mathrm{C}_{15} \mathrm{H}_{23} \mathrm{~N}_{4} \mathrm{O}_{3}[\mathrm{MH}]^{+}$: 307.17647; Found: 307.17718.

Compound $3 \mathbf{f}$. Following the general procedure A, from $0.5 \mathrm{~g}$ of L-Arginine compound $\mathbf{3} \mathbf{f}$ was obtained in $81 \%$ yield. m.p. $138-141{ }^{\circ} \mathrm{C}$. IR (ATR) $v_{\text {máx }}\left(\mathrm{cm}^{-1}\right) 3262,3172,3056,2864,1634,1557,1495,1394$. ${ }^{1} \mathrm{H}$ RMN (400 MHz, $\left.\mathrm{D}_{2} \mathrm{O}\right)$ 8 7.50-7.29 (m, 5H, H-4' $, \mathrm{H}-5^{\prime}, \mathrm{H}-6^{\prime}, \mathrm{H}-7^{\prime}$ e H-8'), 4.19 (dd, J = 8.1, $4.8 \mathrm{~Hz}$, $1 \mathrm{H}, \mathrm{H}-2), 3.68$ (d, $\left.J=14.4 \mathrm{~Hz}, 1 \mathrm{H}, \mathrm{H}-2^{\prime} \mathrm{a}\right), 3.60$ (d, $\left.J=14.8 \mathrm{~Hz}, 1 \mathrm{H}, \mathrm{H}-2^{\prime} \mathrm{b}\right), 3.11(\mathrm{t}, J=6,9 \mathrm{~Hz}, 2 \mathrm{H}, \mathrm{H}-5)$, 1.89-1.77 (m, 1H, H-3a), 1.75-1.61 (m, 1H, H-3b), 1.59-1.43 (m, 2H, H-4). ${ }^{13} \mathrm{C}$ NMR $\left(101 \mathrm{MHz}, \mathrm{D}_{2} \mathrm{O}\right) \delta$ 178.47 (C-1), 173.97 (C-1'), 156.54 (C-6), 135.15 (C-3'), 129.06 (C-5' e C-7'), 128.89 (C-4' e C-8'), 127.25 (C-6'), 54.57 (C-2), 42.43 (C-2'), 40.49 (C-5), 28.77 (C-3), 24.38 (C-4). HRMS (ESI) $m / z$ calculated for $\mathrm{C}_{14} \mathrm{H}_{21} \mathrm{~N}_{4} \mathrm{O}_{3}[\mathrm{MH}]^{+}$: 293.16082; Found: 293.16134.

Compound 3g. Following the general procedure A, from $0.5 \mathrm{~g}$ of $\mathrm{L}-\mathrm{Arginine}$ compound $\mathbf{3 g}$ was obtained in $38 \%$ yield. m.p. $108-111^{\circ} \mathrm{C}$. IR (ATR) $v_{\operatorname{máx}}\left(\mathrm{cm}^{-1}\right) 3029,1719,1632,1563,1474,1364,1203 .{ }^{1} \mathrm{H}$ RMN $\left(400 \mathrm{MHz}, \mathrm{CD}_{3} \mathrm{OD}\right) \delta 7.23\left(\mathrm{t}, J=7.8 \mathrm{~Hz}, 2 \mathrm{H}, \mathrm{H}-4^{\prime}\right.$ e H-6 $\left.{ }^{\prime}\right), 7.07\left(\mathrm{t}, J=7.2 \mathrm{~Hz}, 1 \mathrm{H}, \mathrm{H}-5^{\prime}\right), 6.99(\mathrm{~d}, J=7.9 \mathrm{~Hz}$, 2H, H-3' e H-7'), 4.01-3.90 (m, 1H, H-2), 3.09 (t, $J=6.6$ Hz, 2H, H-5), 1.91-1.74 (m, 1H, H-3a), 1.74-1.54 (m, 3H, H-3b e H-4). HRMS (ESI) $\mathrm{m} / z$ calculated for $\mathrm{C}_{13} \mathrm{H}_{19} \mathrm{~N}_{4} \mathrm{O}_{4}\left[\mathrm{MH}^{+}\right]$: 295.14008; Found: 295.13994.

Compound 3h. [53]. Following the general procedure $\mathrm{B}$, from $0.5 \mathrm{~g}$ of $\mathrm{L}$-Arginine compound $\mathbf{3 h}$ was obtained in $31 \%$ yield. ${ }^{1} \mathrm{H}$ RMN $\left(400 \mathrm{MHz}, \mathrm{D}_{2} \mathrm{O}\right) \delta 7.73\left(\mathrm{~s}, 1 \mathrm{H}, \mathrm{H}-6^{\prime}\right), 6.97\left(\mathrm{~s}, 1 \mathrm{H}, \mathrm{H}-5^{\prime}\right), 4.37-4.29(\mathrm{~m}$, $\left.1 \mathrm{H}, \mathrm{H}-2^{\prime}\right), 4.18$ (dd, J = 12.4, 5.0 Hz, 1H, H-2), 3.27-3.12 (m, 2H, H-5), 3.12-3.02 (m, 1H, H-3' a), 3.00-2.90 (m, 1H, H-3'b), 1.93-1.78 (m, 1H, H-3a), 1.76-1.62 (m, 1H, H-3b), 1.62-1.48 (m, 2H, H-4), 1.38 (s, 9H, $\left.\mathrm{H}-3^{\prime \prime}\right)$. HRMS (ESI) $m / z$ calculated for $\mathrm{C}_{17} \mathrm{H}_{29} \mathrm{~N}_{7} \mathrm{O}_{5}[\mathrm{MH}]^{+}$: 412.2303; Found: 412.2300 .

\subsection{Synthesis of Carbamimidoyl-L-proline (2) [54]}

To a round-bottom flask charged with a solution L-Proline in a mixture of water (volume to make a $5.7 \mathrm{M}$ solution of substrate) and methanol (volume to make a $4.3 \mathrm{M}$ solution of substrate) a solution of cyanamide (1.5 equiv.) in water (volume to make a $4.8 \mathrm{M}$ solution of substrate) was added and the reaction mixture was stirred at $100{ }^{\circ} \mathrm{C}$ for $16 \mathrm{~h}$. After complete consumption of the starting material, the reaction mixture was concentrated under vacuum and washed several times with isopropanol to afford the desired product as a white solid. ${ }^{1} \mathrm{H}$ NMR $\left(400 \mathrm{MHz}, \mathrm{D}_{2} \mathrm{O}\right) \delta 4.27(\mathrm{dd}, J=8.6,2.9 \mathrm{~Hz}, 1 \mathrm{H})$, 3.62-3.53 (m, 1H), $3.48(\mathrm{dd}, J=16.8,8.7 \mathrm{~Hz}, 1 \mathrm{H}), 2.30(\mathrm{~d}, J=10.9 \mathrm{~Hz}, 1 \mathrm{H}), 2.18(\mathrm{dd}, J=6.5,3.1 \mathrm{~Hz}, 1 \mathrm{H})$, 2.10-1.89 (m, 2H). ${ }^{13} \mathrm{C}$ NMR (101 MHz, $\left.\mathrm{D}_{2} \mathrm{O}\right) \delta 177.77,154.73,62.42,47.82,31.02,23.32$.

\subsection{General Procedure for the Preparation of Compounds 4 from Decarboxylation of Arginine Derivatives}

Following the adapted procedure reported by Huang et al. [40] to a round-bottom flask charged with a solution of derivatized L-arginine in water (volume to make a $0.4 \mathrm{M}$ solution of substrate) at $60{ }^{\circ} \mathrm{C}, \mathrm{CuSO}_{4} \cdot 5 \mathrm{H}_{2} \mathrm{O}$ (1 equiv.) was added, and the solution was stirred for $10 \mathrm{~min}$. Then, $\mathrm{AgNO}_{3}$ ( 0.15 equiv.) and $\mathrm{NH}_{4} \mathrm{~S}_{2} \mathrm{O}_{8}$ (1.5 equiv.) were added and the reaction was stirred at r.t. for $30 \mathrm{~min}$ (the reaction color evolves from blue to a green solution).

After complete consumption of the starting material, the reaction mixture was concentrated under vacuum and purified by RP-18 column chromatography. The collected fractions were analyzed by UV-vis and combined according to the obtained UV-spectra.

Compound 4a. Following the general procedure and starting from $50 \mathrm{mg}$ of $3 \mathbf{a}$ compound $4 \mathrm{a}$ was obtained in $72 \%$ yield. ${ }^{1} \mathrm{H}$ NMR $\left(400 \mathrm{MHz}, \mathrm{D}_{2} \mathrm{O}\right) \delta 7.72(\mathrm{~d}, J=7.5 \mathrm{~Hz}, 1 \mathrm{H}), 7.61(\mathrm{t}, J=7.2 \mathrm{~Hz}, 1 \mathrm{H}), 7.50$ $(\mathrm{t}, J=7.5 \mathrm{~Hz}, 1 \mathrm{H}), 5.87(\mathrm{~d}, J=6.1 \mathrm{~Hz}, 1 \mathrm{H}), 3.60(\mathrm{t}, J=7.5 \mathrm{~Hz}, 1 \mathrm{H}), 3.43(\mathrm{~m}, 1 \mathrm{H}), 2.39-2.07(\mathrm{~m}, 1 \mathrm{H}) .{ }^{13} \mathrm{C}$ NMR $\left(101 \mathrm{MHz}, \mathrm{D}_{2} \mathrm{O}\right) \delta 179.30,171.02,134.50,133.14,129.73,128.06,56.12,41.66,30.03,25.58$. HRMS (ESI) $\mathrm{m} / z$ calculated $\mathrm{C}_{12} \mathrm{H}_{17} \mathrm{~N}_{4} \mathrm{O}[\mathrm{MH}]^{+}:$233.13969; Found: 233.13931 .

Compound $\mathbf{4 b}$. Following the general procedure and starting from $50 \mathrm{mg}$ of $\mathbf{3 b}$ compound $\mathbf{4 b}$ was obtained in $80 \%$ yield. ${ }^{1} \mathrm{H}$ RMN $\left(400 \mathrm{MHz}, \mathrm{D}_{2} \mathrm{O}\right) \delta 7.57\left(\mathrm{~d}, J=8.7 \mathrm{~Hz}, 2 \mathrm{H}, \mathrm{H}-3^{\prime}\right.$ e H-7'), $6.87(\mathrm{~d}$, 
$J=8.7 \mathrm{~Hz}, 2 \mathrm{H}, \mathrm{H}-4^{\prime}$ e $\left.\mathrm{H}-6^{\prime}\right), 5.75-5.64$ (m, 1H, H-2), 3.73 (s, 3H, OMe), 3.54-3.44 (m, 1H, H-5a), 3.38-3.28 (m, 1H, H-5b), 2.27-2.09 (m, 2H, H-3), 2.08-1.94 (m, 2H, H-4). ${ }^{13} \mathrm{C}$ NMR (101 MHz, CD $\left.{ }_{3} \mathrm{OD}\right) \delta 179.18$, $168.46,162.47,158.70,141.31,132.28,130.47,128.91,122.49,119.69,115.25,114.90,114.53,55.82,42.06$, 31.19, 26.32. HRMS (ESI) $\mathrm{m} / \mathrm{z}$ calculated $\mathrm{C}_{13} \mathrm{H}_{19} \mathrm{~N}_{4} \mathrm{O}_{2}[\mathrm{MH}]^{+}: 263.15025$; Found: 263.15060 .

Compound $4 \mathrm{~h}$. Following the general procedure and starting from $50 \mathrm{mg}$ of $3 \mathrm{~h}$ compound $4 \mathrm{~h}$ was obtained in 7\% yield ${ }^{1} \mathrm{H}$ NMR $\left(400 \mathrm{MHz}, \mathrm{D}_{2} \mathrm{O}\right) \delta 8.64(\mathrm{~s}, 1 \mathrm{H}), 7.33(\mathrm{~s}, 1 \mathrm{H}), 5.71(\mathrm{~d}, \mathrm{~J}=5.7 \mathrm{~Hz}, 1 \mathrm{H})$, 4.46-4.34 (m, 1H), 3.61-3.48 (m, 1H), 3.46-3.37 (m, 1H), 2.17-2.07 (m, 1H), 1.96-1.92 (m, 2H), 1.80-1.70 $(\mathrm{m}, 1 \mathrm{H}), 1.68-1.51(\mathrm{~m}, 2 \mathrm{H}), 1.39 \mathrm{(s}, 9 \mathrm{H})$ (observed in the crude mixture). ESI-HPLC-MS, RT $12.6 \mathrm{~min}$, $[\mathrm{M}+\mathrm{H}]^{+} \mathrm{m} / z: 412.2 ;[\mathrm{M}-\mathrm{H}]^{+} m / z: 410.2 ; \mathrm{RT} 12.8 \mathrm{~min},[\mathrm{M}+\mathrm{H}]^{+} \mathrm{m} / z: 412.2 ;[\mathrm{M}-\mathrm{H}]^{+} m / z: 410.1$. HRMS (ESI) $m / z$ calculated $\mathrm{C}_{16} \mathrm{H}_{28} \mathrm{~N}_{7} \mathrm{O}_{3}[\mathrm{MH}]^{+}$: 366.2248; Found: 366.2245 .

\subsection{General Procedure for the Preparation of Compounds $\mathbf{4}$ from Decarboxylation of Carbamimidoyl-L-proline (2)}

Following the adapted procedure reported by Huang et al. [40], to a round-bottom flask charged with a solution of derivatized $\mathrm{L}$-Proline in water (volume to make a $0.8 \mathrm{M}$ solution of substrate) at r.t., $\mathrm{CuSO}_{4} \cdot 5 \mathrm{H}_{2} \mathrm{O}$ (1 equiv.), $\mathrm{AgNO}_{3}$ (0.15 equiv.) and $\mathrm{NH}_{4} \mathrm{~S}_{2} \mathrm{O}_{8}$ (1.5 equiv.) were added and the reaction was stirred for $30 \mathrm{~min}$ at r.t. Then, the reaction was heated to $60^{\circ} \mathrm{C}$ and Amberlyst $15(15 \%$ weight of substrate) and the corresponding nucleophile (1.1 equiv.) were added and the reaction was stirred for 16-18 h. After that the reaction mixture was diluted with $\mathrm{MeOH}$ and filtered under a celite pad (washed with water and $\mathrm{MeOH}$ several times). The filtrate was evaporated until dryness and purified by using RP18 column chromatography. The collected fractions were analyzed by UV-vis and combined according to the obtained UV-spectra to afford the desired product.

Compound 1 [17]. Following the general procedure and starting from $100 \mathrm{mg}$ of $\mathbf{2}$ and 1.1 equiv. of amide, compound 1 was obtained in $22 \%$ yield. It is worth to mention that the acetyl group protecting the ferulic amide was removed during the reaction due to the acidic conditions used. ${ }^{1} \mathrm{H}$ NMR $(400 \mathrm{MHz}$, $\left.\mathrm{CD}_{3} \mathrm{OD}\right) \delta 7.54(\mathrm{~d}, J=15.6 \mathrm{~Hz}, 1 \mathrm{H}), 7.11(\mathrm{~d}, J=1.8 \mathrm{~Hz}, 1 \mathrm{H}), 7.03(\mathrm{~d}, J=8.3 \mathrm{~Hz}, 1 \mathrm{H}), 6.79(\mathrm{~d}, J=8.2 \mathrm{~Hz}$, $1 \mathrm{H}), 6.47(\mathrm{~d}, J=15.6 \mathrm{~Hz}, 1 \mathrm{H}), 5.77(\mathrm{~d}, J=5.2 \mathrm{~Hz}, 1 \mathrm{H}), 3.86(\mathrm{~s}, 3 \mathrm{H}), 3.59-3.52(\mathrm{~m}, 1 \mathrm{H}), 3.42-3.35(\mathrm{~m}, 1 \mathrm{H})$, 2.33-2.23 (m, 2H), 2.15-2.08 (m, 1H), 2.04-1.99 (m, 1H). ${ }^{13} \mathrm{C}$ NMR (101 MHz, CD $\left.{ }_{3} \mathrm{OD}\right) \delta 169.96,156.27$, $151.32,149.98,149.55,149.26,144.60,127.80,126.30,123.78,117.06,111.75,64.78,56.13,32.48,24.18$, 23.80. ESI-MS $[\mathrm{M}+\mathrm{H}]^{+} \mathrm{m} / z: 305.1$.

Compound 4a. Following the general procedure and starting from $100 \mathrm{mg}$ of 2 and 1.1 equiv. of benzamide, compound $4 \mathbf{a}$ was obtained in $56 \%$ yield. In accordance with spectra data of compound obtained by method A.

Compound 4c. Following the general procedure and starting from $100 \mathrm{mg}$ of 2 and 1.1 equiv. of amide, compound $4 \mathrm{c}$ was obtained in $22 \%$ yield. ${ }^{1} \mathrm{H}$ NMR $\left(400 \mathrm{MHz},\left(\mathrm{CD}_{3} \mathrm{OD}\right) \delta 7.62(\mathrm{~d}, J=15.8 \mathrm{~Hz}, 1 \mathrm{H})\right.$, $7.60-7.55(\mathrm{~m}, 2 \mathrm{H}), 7.42-7.33(\mathrm{~m}, 3 \mathrm{H}), 6.71(\mathrm{~d}, J=15.7 \mathrm{~Hz}, 1 \mathrm{H}), 5.76(\mathrm{~d}, J=6.1 \mathrm{~Hz}, 1 \mathrm{H}), 3.63-3.53(\mathrm{~m}$, 1H), 3.44-3.34 (m, 1H), 2.39-2.20 (m, 2H), 2.15-1.98 (m, 2H). ${ }^{13} \mathrm{C}$ NMR (101 MHz, CD $\left.{ }_{3} \mathrm{OD}\right) \delta 169.46$, 156.78, 144.14, 135.89, 131.33, 130.04, 129.11, 120.39, 65.27, 48.17, 33.41, 23.77. ESI-MS [M + H] ${ }^{+} \mathrm{m} / z$ : 259.1. HRMS (ESI) $m / z$ calculated $\mathrm{C}_{14} \mathrm{H}_{19} \mathrm{~N}_{4} \mathrm{O}[\mathrm{MH}]^{+}:$259.15534; Found: 259,1561.

Compound 4d. Following the general procedure and starting from $100 \mathrm{mg}$ of 2 and 1.1 equiv. of amide, compound $4 \mathrm{~d}$ was obtained in $32 \%$ yield. ${ }^{1} \mathrm{H}$ NMR $\left(400 \mathrm{MHz}, \mathrm{CD}_{3} \mathrm{OD}\right) \delta 7.28-7.22(\mathrm{~m}, 2 \mathrm{H}), 7.20-7.13$ $(\mathrm{m}, 3 \mathrm{H}), 5.59(\mathrm{~d}, J=5.4 \mathrm{~Hz}, 1 \mathrm{H}), 3.43(\mathrm{dd}, J=12.5,5.3 \mathrm{~Hz}, 1 \mathrm{H}), 3.33(\mathrm{dd}, J=9.0,6.9 \mathrm{~Hz}, 1 \mathrm{H}), 2.90$ $(\mathrm{t}, J=7.4 \mathrm{~Hz}, 2 \mathrm{H}), 2.53(\mathrm{t}, J=7.4 \mathrm{~Hz}, 2 \mathrm{H}), 2.23-2.00(\mathrm{~m}, 2 \mathrm{H}) .{ }^{13} \mathrm{C}$ NMR $\left(101 \mathrm{MHz}, \mathrm{CD}_{3} \mathrm{OD}\right) \delta 180.48$, $175.53,156.79,136.18,130.08,129.59,128.06,65.27,43.17,33.28,24.26,23.69$. ESI-MS $[\mathrm{M}+\mathrm{H}]^{+} \mathrm{m} / z$ : 261.1. HRMS (ESI) $\mathrm{m} / z$ calculated $\mathrm{C}_{14} \mathrm{H}_{21} \mathrm{~N}_{4} \mathrm{O}[\mathrm{MH}]^{+}:$261.17154; Found: 261.1718.

Compound 4e. Following the general procedure $\mathrm{f}$ and starting from $100 \mathrm{mg}$ of $\mathbf{2}$ and 1.1 equiv. of amide, compound $4 \mathrm{e}$ was obtained in $17 \%$ yield. ${ }^{1} \mathrm{H}$ NMR $\left(400 \mathrm{MHz}, \mathrm{CD}_{3} \mathrm{OD}\right) \delta 7.31-7.17(\mathrm{~m}, J=11.7,7.6 \mathrm{~Hz}$, $1 \mathrm{H}), 5.66(\mathrm{~d}, J=5.2 \mathrm{~Hz}, 1 \mathrm{H}), 3.57-3.51(\mathrm{~m}, 3 \mathrm{H}), 3.41-3.33(\mathrm{~m}, 1 \mathrm{H}), 2.31-2.21(\mathrm{~m}, 2 \mathrm{H}), 2.14-2.07(\mathrm{~m}, 1 \mathrm{H})$, 
2-1.95 (m, 1H). ${ }^{13} \mathrm{C}$ NMR (101 MHz, CD $\left.3 \mathrm{OD}\right) \delta 176.66,156.72,141.66,129.49,127.33,64.96,48.00,38.34$, 33.08, 32.56, 23.87, 23.55. HRMS (ESI) $m / z$ calculated $\mathrm{C}_{13} \mathrm{H}_{19} \mathrm{~N}_{4} \mathrm{O}[\mathrm{MH}]^{+}$: 247.15589; Found: 247.1560.

Compound 4f. Following the general procedure and starting from $100 \mathrm{mg}$ of 2 and 1.1 equiv. of amide, compound $4 \mathrm{f}$ was obtained in 51\% yield. ${ }^{1} \mathrm{H}$ NMR $\left(400 \mathrm{MHz}, \mathrm{D}_{2} \mathrm{O}\right) \delta 6.36-6.29(\mathrm{~m}, 2 \mathrm{H}), 5.80(\mathrm{~d}$, $J=2.6 \mathrm{~Hz}, 1 \mathrm{H}), 5.79-5.75(\mathrm{~m}, 1 \mathrm{H}), 3.62-3.54(\mathrm{~m}, 1 \mathrm{H}), 3.46-3.38(\mathrm{~m}, 1 \mathrm{H}), 2.33-2.26(\mathrm{~m}, 2 \mathrm{H}), 2.17-2.10(\mathrm{~m}$, 1H), 2.04-1.98 (m, 1H). ${ }^{13} \mathrm{C}$ NMR (101 MHz, D $\left.{ }_{2} \mathrm{O}\right) \delta 167.55,129.37,127.98,63.83,46.81,31.93,22.30$. HRMS (ESI) $m / z$ calculated $\mathrm{C}_{8} \mathrm{H}_{15} \mathrm{~N}_{4} \mathrm{O}[\mathrm{MH}]^{+}$: $183.1240 ;$ Found: 183.1236.

Compound 4g. Following the general procedure and starting from $100 \mathrm{mg}$ of 2 and 1.1 equiv. of amide, compound $4 \mathrm{~g}$ was obtained in 51\% yield. ${ }^{1} \mathrm{H} \mathrm{NMR}\left(400 \mathrm{MHz}, \mathrm{D}_{2} \mathrm{O}\right) \delta 5.66(\mathrm{~d}, \mathrm{~J}=5.6 \mathrm{~Hz}$, $1 \mathrm{H}), 3.63-352(\mathrm{~m}, 1 \mathrm{H}), 3.44-3.32(\mathrm{~m}, 2 \mathrm{H}), 2.32-2.06(\mathrm{~m}, 4 \mathrm{H}), 2.02(\mathrm{~s}, 3 \mathrm{H}) .{ }^{13} \mathrm{C} \mathrm{NMR}\left(101 \mathrm{MHz}, \mathrm{D}_{2} \mathrm{O}\right) \delta$ 173.37, 155.36, 63.69, 46.72, 31.84, 22.27, 21.01. HRMS (ESI) $m / z$ calculated $\mathrm{C}_{7} \mathrm{H}_{15} \mathrm{~N}_{4} \mathrm{O}[\mathrm{MH}]^{+}: 171.1240$; Found: 171.1241 .

\section{Conclusions}

The first metal catalysed decarboxylative coupling of amino acids bearing basic residues were here described. In this process, nitrogen nucleophiles were used for the first time for the iminium trapping through intermolecular reactions. Excitingly, through this method, novel approaches to a challenging and unusual amino-pyrrolidin-guaninium core were reported. This privileged structure is an unexplored motif in natural products and very promising for the design of bioactive synthetic derivatives. Moreover, efforts are being devoted to establish an enantioselective approach for the synthesis of compound 4. Also, the promising result obtained with the dipeptide $3 \mathrm{~h}$ where compound 4h was obtained, definitely makes the preparation of novel peptidomimetics within reach.

Supplementary Materials: The following are available online. 1H, 13C, DEPT 135 and Mass spectra of compounds 1, 2, 3a-h and $4 \mathbf{a}-\mathbf{h}$ and Figure S1-S4.

Author Contributions: The contributions of the authors to this work is as follows: Conceptualization, P.S.B. and L.M.F.; methodology, P.S.B. and L.M.F.; formal analysis, A.L.; laboratory work, R.R., L.P. and M.L.; writing—original draft preparation, P.S.B., L.M.F., R.R., L.P.; writing—review and editing, P.S.B., L.M.F. and A.L.; project administration, A.L.; funding acquisition, P.S.B., L.M.F. and A.L. All authors have read and agreed to the published version of the manuscript.

Funding: This work was supported by the Associate Laboratory for Green Chemistry-LAQV, which is financed by national funds from FCT/MCTES (UIDB/50006/2020). The National NMR Facility and the SCXRD facility are supported by Fundação para a Ciência e Tecnologia (RECI/BBB-BQB/0230/2012 and RECI/BBB-BEP/0124/2012, respectively). R.R. also acknowledgments the grant number SFRH/BD/136692/2018 from FCT/MCTES.

Acknowledgments: We acknowledge the Laboratório de Análises REQUIMTE for the technical support for the mass spectrometry analyses.

Conflicts of Interest: The authors declare no conflict of interest.

\section{References}

1. Nadin, A.; Hattotuwagama, C.; Churcher, I. Lead-oriented synthesis: A new opportunity for synthetic chemistry. Angew. Chem. Int. Edit. 2012, 51, 1114-1122. [CrossRef] [PubMed]

2. Mitchison, T.J. Small-molecule screening and profiling by using automated microscopy. Chembiochem 2005, 6, 33-39. [CrossRef] [PubMed]

3. de la Torre, B.G.; Albericio, F. The pharmaceutical industry in 2018. An analysis of fda drug approvals from the perspective of molecules. Molecules 2019, 24, 12. [CrossRef] [PubMed]

4. Dobson, C.M. Chemical space and biology. Nature 2004, 432, 824-828. [CrossRef]

5. Erlanson, D.A.; Fesik, S.W.; Hubbard, R.E.; Jahnke, W.; Jhoti, H. Twenty years on: The impact of fragments on drug discovery. Nat. Rev. Drug Discov. 2016, 15, 605-619. [CrossRef]

6. Lourenco, A.M.; Ferreira, L.M.; Branco, P.S. Molecules of natural origin, semi-synthesis and synthesis with anti-inflammatory and anticancer utilities. Curr. Pharm. Design 2012, 18, 3979-4046. [CrossRef] 
7. Karageorgis, G.; Waldmann, H. Guided by evolution: Biology-oriented synthesis of bioactive compound classes. Synthesis 2019, 51, 55-66. [CrossRef]

8. Newman, D.J.; Cragg, G.M. Natural products as sources of new drugs from 1981 to 2014. J. Nat. Prod. 2016, 79, 629-661. [CrossRef]

9. Berlinck, R.G.S.; Bertonha, A.F.; Takaki, M.; Rodriguez, J.P.G. The chemistry and biology of guanidine natural products. Nat. Prod. Rep. 2017, 34, 1264-1301. [CrossRef]

10. Liu, J.; Li, X.W.; Guo, Y.W. Recent advances in the isolation, synthesis and biological activity of marine guanidine alkaloids. Mar. Drugs 2017, 15, 324. [CrossRef]

11. McTaggart, F.; Buckett, L.; Davidson, R.; Holdgate, G.; McCormick, A.; Schneck, D.; Smith, G.; Warwick, M. Preclinical and clinical pharmacology of rosuvastatin, a new 3-hydroxy-3-methylglutaryl coenzyme a reductase inhibitor. Am. J. Cardiol. 2001, 87, 28-32. [CrossRef]

12. Capuzzi, D.M.; Cevallos, W.H. Inhibition of hepatic cholesterol and triglyceride synthesis by guanabenz acetate. J. Cardiovasc. Pharmacol. 1984, 6, S847-S852. [CrossRef]

13. Fabbro, D.; Parkinson, D.; Matter, A. Protein tyrosine kinase inhibitors: New treatment modalities? Curr. Opin. Pharmacol. 2002, 2, 374-381. [CrossRef]

14. Carter, D.C.; Logan, R.; Forrest, J.A.H.; Ansell, I.; Heading, R.C.; Shearman, D.J.C. Effect of histamine h2 receptor antagonist, cimetidine, on insulin-induced gastric-secretion in man. Br. J. Surg. 1975, 62, 664-665.

15. Saczewski, F.; Balewski, L. Biological activities of guanidine compounds, 2008-2012 update. Expert Opin. Ther. Patents 2013, 23, 965-995. [CrossRef]

16. Coles, M.P. Bicyclic-guanidines, -guanidinates and -guanidinium salts: Wide ranging applications from a simple family of molecules. Chem. Commun. 2009, 3659-3676. [CrossRef]

17. Lopes, L.C.; Roman, B.; Medeiros, M.A.; Mukhopadhyay, A.; Utrilla, P.; Galvez, J.; Maurino, S.G.; Moltiva, V.; Lourenco, A.; Feliciano, A.S. Cernumidine and isocernumidine, new type of cyclic guanidine alkaloids from solanum cernuum. Tetrahedron Lett. 2011, 52, 6392-6395. [CrossRef]

18. Kundu, J.K.; Surh, Y.J. Breaking the relay in deregulated cellular signal transduction as a rationale for chemoprevention with anti-inflammatory phytochemicals. Mutat. Res.-Fundam. Mol. Mech. Mutagen. 2005, 591, 123-146. [CrossRef]

19. Kundu, J.K.; Surh, Y.J. Emerging avenues linking inflammation and cancer. Free Radic. Biol. Med. 2012, 52, 2013-2037. [CrossRef]

20. Brew, R.; Erikson, J.S.; West, D.C.; Kinsella, A.R.; Slavin, J.; Christmas, S.E. Interleukin-8 as an autocrine growth factor for human colon carcinoma cells in vitro. Cytokine 2000, 12, 78-85. [CrossRef]

21. Miranda, M.A.; Mondal, A.; Sachdeva, M.; Cabral, H.; Neto, Y.; Khan, I.; Groppo, M.; McChesney, J.D.; Bastos, J.K. Chemosensitizing effect of cernumidine extracted from solanum cernuum on bladder cancer cells in vitro. Chem. Biodivers. 2019, 16, e1900334. [CrossRef]

22. Damasceno, J.L.; de Oliveira, P.F.; Miranda, M.A.; Lima, M.; Bastos, J.K.; Tavares, D.C. Antigenotoxic and antioxidant properties of solanum cernuum and its alkaloid, cernumidine. Biol. Pharm. Bull. 2016, 39, 920-926. [CrossRef]

23. Ramos, A.C.; de Oliveira, R.R. A new alkaloid and flavonoids isolated from solanum cernuum leaves by high-performance countercurrent chromatography. Nat. Prod. Res. 2017, 31, 2405-2412. [CrossRef] [PubMed]

24. Ascenzi, P.; Fasano, M.; Marino, M.; Venturini, G.; Federico, R. Agmatine oxidation by copper amine oxidase-Biosynthesis and biochemical characterization of N-amidino-2-hydroxypyrrolidine. Eur. J. Biochem. 2002, 269, 884-892. [CrossRef] [PubMed]

25. Boto, A.; Hernandez, R.; Suarez, E. Oxidative decarboxylation of alpha-amino acids: A mild and efficient method for the generation of N-acyliminium ions. Tetrahedron Lett. 1999, 40, 5945-5948. [CrossRef]

26. Boto, A.; Hernandez, R.; Suarez, E. Synthesis of alkaloids from amino acids via N-acyliminium ions generated by one-pot radical decarboxylation-oxidation. Tetrahedron Lett. 2000, 41, 2899-2902. [CrossRef]

27. Boto, A.; Hernandez, R.; Suarez, E. Tandem radical decarboxylation-oxidation of amino acids: A mild and efficient method for the generation of $\mathrm{N}$-acyliminium ions and their nucleophilic trapping. J. Org. Chem. 2000, 65, 4930-4937. [CrossRef]

28. Boto, A.; Hernandez, R.; Suarez, E. Tandem oxidative radical decarboxylation-beta-iodination of amino acids. Application to the synthesis of chiral 2,3-disubstituted pyrrolidines. Tetrahedron Lett. 2000, 41, 2495-2498. [CrossRef] 
29. Silva, S.B.L.; Oberhansli, F.; Tribalat, M.A.; Genta-Jouve, G.; Teyssie, J.L.; Dechraoui-Bottein, M.Y.; Gallard, J.F.; Evanno, L.; Poupon, E.; Thomas, O.P. Insights into the biosynthesis of cyclic guanidine alkaloids from crambeidae marine sponges. Angew. Chem. Int. Edit. 2019, 58, 520-525. [CrossRef]

30. Fan, R.H.; Li, W.X.; Wang, B. A one-pot oxidative decarboxylation-friedel-crafts reaction of acyclic alpha-amino acid derivatives activated by the combination of iodobenzene diacetate/iodine and iron dust. Org. Biomol. Chem. 2008, 6, 4615-4621. [CrossRef]

31. Cowden, C.J. Use of N-protected amino acids in the minisci radical alkylation. Org. Lett. 2003, 5, 4497-4499. [CrossRef]

32. Bellale, E.V.; Huddar, S.N.; Mahajan, U.S.; Akamanchi, K.G. Oxidative decarboxylation of alpha-amino acids to nitriles using o-iodoxybenzoic acid in aqueous ammonia. Pure Appl. Chem. 2011, 83, 607-612. [CrossRef]

33. Matthessen, R.; Claes, L.; Fransaer, J.; Binnemans, K.; De Vos, D.E. Decarboxylation of a wide range of amino acids with electrogenerated hypobromite. Eur. J. Org. Chem. 2014, 6649-6652. [CrossRef]

34. Laval, G.; Golding, B.T. One-pot sequence for the decarboxylation of alpha-amino acids. Synlett 2003, 542-546.

35. Bacon, R.G.R.; Hanna, W.J.W.; Stewart, D. Oxidation by persulphate. Part V. Silver-catalysed oxidation of secondary aliphatic amines and $\alpha$-amino-acids. J. Chem. Soc. C 1966, 1388-1389. [CrossRef]

36. Clarke, T.G.; Hampson, N.A.; Lee, J.B.; Morley, J.R.; Scanlon, B. Oxidations involving silver. II. Oxidation of alcohols and aldehydes with silver(II) picolinate. Can. J. Chem. 1969, 47, 1649-1654. [CrossRef]

37. Zelechonok, Y.; Silverman, R.B. Silver(I)/peroxydisulfate-induced oxidative decarboxylation of amino-acids-A chemical-model for a possible intermediate in the monoamine oxidase-catalyzed oxidation of amines. J. Org. Chem. 1992, 57, 5787-5790. [CrossRef]

38. Anderson, J.M.; Kochi, J.K. Silver(I)-catalyzed oxidative decarboxylation of acids by peroxydisulfate-Role of silver(II). J. Am. Chem. Soc. 1970, 92, 1651-1659. [CrossRef]

39. Fristad, W.E.; Fry, M.A.; Klang, J.A. Persulfate silver ion decarboxylation of carboxylic-acids—Preparation of alkanes, alkenes, and alcohols. J. Org. Chem. 1983, 48, 3575-3577. [CrossRef]

40. Huang, W.H.; Wang, M.L.; Yue, H. Conversion of N-acyl amino acids into imides via oxidative decarboxylation induced by $\mathrm{Ag}^{+} / \mathrm{Cu}^{2+} / \mathrm{S}_{2} \mathrm{O}_{8}{ }^{2-}$ in water. Synthesis 2008, 1342-1344. [CrossRef]

41. Bi, H.P.; Chen, W.W.; Liang, Y.M.; Li, C.J. A novel iron-catalyzed decarboxylative Csp ${ }^{3}$-Csp ${ }^{2}$ coupling of proline derivatives and naphthol. Org. Lett. 2009, 11, 3246-3249. [CrossRef] [PubMed]

42. Xu, K.; Wang, Z.Q.; Zhang, J.J.; Yu, L.T.; Tan, J.J. Cobalt-catalyzed decarboxylative acetoxylation of amino acids and arylacetic acids. Org. Lett. 2015, 17, 4476-4478. [CrossRef] [PubMed]

43. Zhang, C.; Seidel, D. Nontraditional reactions of azomethine ylides: Decarboxylative three-component couplings of alpha-amino acids. J. Am. Chem. Soc. 2010, 132, 1798-1799. [CrossRef] [PubMed]

44. Bi, H.P.; Zhao, L.; Liang, Y.M.; Li, C.J. The copper-catalyzed decarboxylative coupling of the sp ${ }^{3}$-hybridized carbon atoms of alpha-amino acids. Angew. Chem. Int. Edit. 2009, 48, 792-795. [CrossRef]

45. Firouzabadi, H.; Iranpoor, N.; Ghaderi, A.; Ghavami, M. Cerium(IV) oxide as a neutral catalyst for aldehyde-induced decarboxylative coupling of L-proline with triethyl phosphite and nitromethane. Tetrahedron Lett. 2012, 53, 5515-5518. [CrossRef]

46. Rahman, M.; Mukherjee, A.; Kovalev, I.S.; Kopchuk, D.S.; Zyryanov, G.V.; Tsurkan, M.V.; Majee, A.; Ranu, B.C.; Charushin, V.N.; Chupakhin, O.N.; et al. Recent advances on diverse decarboxylative reactions of amino acids. Adv. Synth. Catal. 2019, 361, 2161-2214. [CrossRef]

47. Zervas, L.; Winitz, M.; Greenstein, J.P. Studies on arginine peptides.1. Intermediates in the synthesis of N-terminal and C-terminal arginine peptides. J. Org. Chem. 1957, 22, 1515-1521. [CrossRef]

48. Vaidyanathan, R.; Kalthod, V.G.; Ngo, D.P.; Manley, J.M.; Lapekas, S.P. Amidations using $N, N^{\prime}$-carbonyldiimidazole: Remarkable rate enhancement by carbon dioxide. J. Org. Chem. 2004, 69, 2565-2568. [CrossRef]

49. Kiyokawa, K.; Watanabe, T.; Fra, L.; Kojima, T.; Minakata, S. Hypervalent iodine(III)-mediated decarboxylative ritter-type amination leading to the production of alpha-tertiary amine derivatives. J. Org. Chem. 2017, 82, 11711-11720. [CrossRef]

50. Richards, J.C.; Spenser, I.D. H-2 NMR-spectroscopy as a probe of the stereochemistry of enzymic reactions at prochiral centers-Diamine oxidase. Tetrahedron 1983, 39, 3549-3568. [CrossRef] 
51. Nagao, Y.; Miyasaka, T.; Seno, K.; Fujita, E.; Shibata, D.; Doi, E. Utilization of sulfur-containing leaving group.6. Peptide-bond formation, chemoselective acylation of amino-acids, and crosslinking reaction between amino-acids utilizing a functional 5-membered heterocycle, 1,3-thiazolidine-2-thione. J. Chem. Soc.-Perkin Trans. 1984, 1, 2439-2446. [CrossRef]

52. Sahakitpichan, P.; Disadee, W.; Ruchirawat, S.; Kanchanapoom, T. L-(N-trans-cinnamoyl)-arginine, an acylamino acid from Glinus oppositifolius (L.) Aug. DC. Molecules 2010, 15, 6186-6192. [CrossRef] [PubMed]

53. Mahindra, A.; Bagra, N.; Wangoo, N.; Khan, S.I.; Jacob, M.R.; Jain, R. Discovery of short peptides exhibiting high potency against cryptococcus neoformans. ACS Med. Chem. Lett. 2014, 5, 315-320. [CrossRef] [PubMed]

54. Rowley, G.L.; Greenleaf, A.L.; Kenyon, G.L. Specificity of creatine kinase-new glycocyamines and glycocyamine analogs related to creatine. J. Am. Chem. Soc. 1971, 93, 5542-5551. [CrossRef] [PubMed]

Sample Availability: Samples of the compounds are available from the authors.

(C) 2020 by the authors. Licensee MDPI, Basel, Switzerland. This article is an open access article distributed under the terms and conditions of the Creative Commons Attribution (CC BY) license (http://creativecommons.org/licenses/by/4.0/). 